Mexican Journal of Biotechnology 2020, 5(2):1-50

Journal homepage:www.mexjbiotechnol.com

ISSN:2448-6590

\title{
A 21st century miniguide to sporophore morphogenesis and development in Agaricomycetes and their biotechnological potential
}

\section{Una miniguía del siglo XXI para la morfogénesis y desarrollo del esporocarpo en Agaricomicetos y su potencial biotecnológico}

\author{
Mark G. Loftus ${ }^{1}$, Carmen Sánchez ${ }^{2}$, David Moore ${ }^{3}$, Geoff Robson ${ }^{3}$ \& Tony Trinci ${ }^{3}$
}

${ }^{1}$ Sylvan Inc, Pennsylvania, United States of America.

${ }^{2}$ Research Centre for Biological Sciences, Universidad Autónoma de Tlaxcala, Tlaxcala, México.

${ }^{3}$ School of Biological Sciences, Faculty of Biology, Medicine and Health, The University of Manchester, United Kingdom (retired).

${ }^{*}$ Corresponding author

E-mail address: carmen.sanchezh@uatx.mx (C. Sánchez)

Article history:

Received: 9 January 2020 / Received in revised form: 12 March 2019 / Accepted: 15 March 2020 / Published online: 1 April 2020.

https://doi.org/10.29267/mxib.2020.5.2.1

\begin{abstract}
We review the most recent developments in understanding the nature of development and morphogenesis in fungi and suggest how it might be applied to biotechnological manipulation of some cultivated mushrooms. We believe that it is essential to match the deductions of the molecular observations of the genomics generation with the inductive reasoning of the in vivo experiments and observations of the pregenomics generations to take full advantage of the synergism between the approaches to illuminate better the living biology of the system. As specific examples we show how model mushroom fungi (Coprinopsis and Volvariella) make hymenia and gills (not forgetting how the polypore Phellinus makes tubes), developmental commitment and pattern formation. The Coprinopsis sporophore also provides examples for the construction of mushroom stems and the co-ordination of cell behaviour throughout the maturing sporophore and the timing process that achieves that. This leads us to consider the mechanics of the mushroom and its dependence on the biochemistry and regulation of metabolism in relation to morphogenesis, and how it varies between species. We finish with our summary of the basic principles of fungal developmental biology. Having demonstrated how classic approaches allowed progress to be made in the study of fungal development we show how this has been accelerated by genomics and other aspects of global analysis of macromolecules. We also include work on some cultivated mushrooms to illustrate how the generalisations from research on model organisms might be applied in mushroom farming.
\end{abstract}


Keywords: agaric, agronomics, biocontrol, breeding, cultivated mushroom, development, differentiation, drug discovery, farm, genomics, model species, morphogenesis, nutraceutical, remediation, sporophore, transcriptomics.

\section{RESUMEN}

En esta revisión mostramos los avances más recientes para entender la naturaleza del desarrollo y la morfogénesis de los hongos y sugerimos cómo podrían aplicarse a la manipulación biotecnológica de algunos hongos cultivados. Consideramos que es esencial complementar las observaciones moleculares de la generación genómica con el razonamiento inductivo de los experimentos in vivo y con las observaciones de la generación pregenómica para aprovechar totalmente el sinergismo entre los enfoques e ilustrar mejor la biología del sistema. Como ejemplos específicos mostramos cómo los hongos modelo seta (Coprinopsis y Volvariella) hacen himenia y branquias (sin olvidar cómo el políporo Phellinus hace tubos), con compromiso de desarrollo y formación de patrones. Los esporocarpos del género Coprinopsis también proporcionan ejemplos para la formación de estípites en hongos setas y para la coordinación del comportamiento celular a través del esporocarpo maduro durante el tiempo requerido para que esto ocurra. Esto nos lleva a considerar la mecánica del hongo y su dependencia de la bioquímica y regulación del metabolismo en relación con la morfogénesis, y cómo varía entre especies. Finalmente, resumimos los principios básicos de la biología del desarrollo de los hongos. Después de haber demostrado cómo los enfoques clásicos permitieron avanzar en el estudio del desarrollo de los hongos, mostramos cómo esto ha sido acelerado por la genómica y otros aspectos del análisis global de las macromoléculas. También incluimos trabajos sobre algunos hongos cultivados para ilustrar cómo las generalizaciones de la investigación sobre organismos modelo podrían aplicarse en el cultivo de setas.

Palabras clave: agárico, agronómica, biocontrol, desarrollo, diferenciación, descubrimiento de fármacos, especies modelo, esporocarpo, genómica, hongos cultivados, morfogénesis, nutracéutico, planta productora de hongos, remediación, transcriptómica.

\section{INTRODUCTION}

Fungal hyphae are capable of a wide range of cell differentiation, in particular producing a great variety of multicellular sporophores (sexual and asexual). So, it is clearly evident, that a fungal mycelium has a number of alternative developmental pathways open to it:

- continuation of hyphal growth

- production of asexual structures

- $\quad$ progress into the sexual cycle.

These are not strict alternatives, because a mycelium of even modest size may express all of these possibilities at the same time, so we can deduce that whatever control of genetic expression is involved must be local.

In this paper we use some material extracted, with permission, from the second edition of the book 21st Century Guidebook to Fungi [www.cambridge.org/9781108745680] (Moore et al., 2020) to review the most recent developments in understanding the nature of development and morphogenesis in fungi and suggest how it might be applied to biotechnological manipulation of some cultivated mushrooms. 20th century observational and experimental developmental biology led to the conclusion that there are several ways to 'make a mushroom', depending upon different arrangements of competence and regional patterning within different sporophores (Watling \& Moore, 1994). The most recent and extensive megaphylogenomics analysis of mushroom evolution also concludes that '...several clade-specific adaptive radiations and morphological diversification of fruiting bodies 
followed during the Cretaceous and the Paleogene, convergently giving rise to the classic toadstool morphology, with a cap, stalk and gills (pileate-stipitate morphology). This morphology is associated with increased rates of lineage diversification, suggesting it represents a key innovation in the evolution of mushroom-forming fungi (Varga et al., 2019)...'

We believe that it is essential to match the deductions of the molecular observations of the genomics generation with the inductive reasoning of the in vivo experiments and observations of the pregenomics generation to take full advantage of the synergism between the approaches better to illuminate the living biology of the system. Indeed, discussion of cell differentiation and morphogenetic fields in fungal sporophores extend back into the nineteenth century (Fayod, 1889), the 1930s (Corner, 1932) and 1960s (Reijnders, 1963; Corner, 1966); it is important that such perceptive interpretations are not lost beneath the omics tsunami.

\section{DEVELOPMENT AND MORPHOGENESIS}

In a great many fungi, hyphae differentiate from the vegetative form that ordinarily composes a mycelium and aggregate to form tissues of multihyphal structures. The tissue may form linear organs (that emphasise parallel arrangements of hyphae), such as strands, rhizomorphs and sporophore stems); or globose masses (that emphasise interweaving of hyphae), such as sclerotia, sporophores and other sporulating structures of the larger Ascomycota and Basidiomycota.

Development of any of these fungal multicellular structures requires that hyphal growth takes on a particular 'pattern'. A 'pattern' that, time after time, produces the same species-specific structure and morphology of that structure, a process that demands precise control and regulation. Formation of a multicellular structure begins with a localised association of aerial hyphae into hyphal tufts (also called Reijnders' hyphal knots), which gradually enlarge and differentiate into a primordium of the sporophore (or other structure, according to circumstances) from which the sporophore (etc.) finally emerges (Moore, 1995).

The differential growth represented in this morphogenesis, and which gives rise to the development of the variety of tissues that make up a fungal multicellular structure involves detailed control and regulation of wall synthesis. Most descriptions of wall formation concentrate on hyphal apical growth, but in development of multicellular structures, 'mature' hyphal wall distant from its hyphal apex can restart wall formation to remodel and reshape the cell. There are many observations of hyphal walls being thickened internally by synthesis of a secondary wall, mostly made up of thick fibrils, which are probably constructed of glucans accumulated as a nutritional reserve (see Chapter 7 in Moore et al., 2020).

Differentiation events can be limited to particular hyphae within the structure (indeed, to particular cell compartments in individual hyphae), and differential growth of tissues can generate mechanical forces that change the macroscopic shape of the whole structure. In developmental terminology this is pattern formation (creation of a particular spatial arrangement of tissues that will generate the final morphology of the structure or organ) caused by regional patterning (regional specification) of the differentiation pathways followed by the cells within those patterns. Pattern formation and regional specification are examples of development-specific terminology, most of which has been coined in conjunction with research on animals, so it is appropriate to consider how far it can be applied to fungi.

But first we want to make a point about 'real world' mushroom development and differentiation as it occurs on a mushroom farm. Once the compost is completely colonised, the challenge is to turn the fungal biomass into mushrooms. In order to expedite mushroom formation, a layer of buffered peat or coir is applied on top of the compost. This casing layer is at field capacity for moisture and is around $\mathrm{pH} 8$, and additionally is low in nutritional value. The mushroom grower will then allow the casing layer to be colonised by mushroom mycelium, and then the room will be 'flushed' to reduce the $\mathrm{CO}_{2}$ level to below $1000 \mathrm{ppm}$ and reduce the air temperature to around $17^{\circ} \mathrm{C}$, together with heavy application of 
water. In other words, reduced temperature and reduced $\mathrm{CO}_{2}$ concentration are triggers for mushroom formation in Agaricus.

There is another, perhaps more interesting factor occurring in the casing layer on a mushroom farm. Back in the 1970s, it became clear that Pseudomonas bacteria played a role in stimulating pin initiation (Hayes et al., 1969). Later work by Noble et al. (2009) further refined the role of bacteria, with Pseudomonas metabolising Agaricus VOCs (Volatile Organic Compounds). This change in the chemistry of the casing layer stimulates pin formation. It is unclear if bacteria fulfil similar roles in other mushroom forming fungi in vivo.

Mushrooms of the genus Pleurotus are cultivated on a variety of lignocellulosic substrates. Mushroom shelves, suspended systems and plastic bags with perforations are the main substrate containers used for Pleurotus cultivation (Sánchez, 2010). The pasteurized substrate is spawned and placed into the container, which is maintained under the temperature, moisture and other conditions optimal for mycelium growth and fruiting. Fruiting initiation can be triggered by a variety of environmental and physicochemical stimuli. In bags used for cultivation, mushrooms begin to form around the edges of the bag's perforations, which indicates that higher levels of oxygen are needed for fruiting. The influence of several factors on fruiting and fruit body development, such as humidity, light, oxygen, temperature, $\mathrm{pH}$, and medium composition (among others) have been studied over the years (Chang \& Miles, 2004; Upadhyay \& Singh, 2010; Sánchez, 2010; Sakamoto et al., 2018; Bellettini et al., 2019). The cellular age is also crucial for fruiting. It was observed that changes during hyphal maturation appear to prepare the mycelia for the formation of fruit body initials in Pleurotus pulmonarius. In mature hyphae, glucan content and protease activity are increased, whereas protein content is reduced, and laccases and $\beta$-1,3-glucanases showed less activity (Sánchez et al., 2004). In addition, the effect of some substances of natural or synthetic origin has been studied in fruit body formation. Berne et al. (2007) studied the effect of ostreolysin, a cytolytic protein specifically expressed during the formation of primordia and fruit bodies of $P$. ostreatus, which slightly inhibited the mycelial growth but strongly induced primordium formation in agar plates. Ostreolysin also stimulated the subsequent development of primordia into fruit bodies.

In the natural environment, Volvariella volvacea, the Chinese straw mushroom, is found in tropical and subtropical grasslands. The vegetative mycelium grows optimally at 32 to $35^{\circ} \mathrm{C}$ but cannot tolerate temperatures below $10^{\circ} \mathrm{C}$ ( $\mathrm{Li}$ et al., 1992). V. volvacea has been widely cultivated on a commercial scale in many parts of Asia; indeed, it may have been in cultivation longer than any other mushroom (Singer, 1961) and in many markets this is the preferred fresh culinary mushroom owing to its unique flavour (Mau et al., 1997). Traditional cultivation mainly uses rice straw (hence its alternative common name of paddy straw mushroom), although several other agricultural wastes (and industrial materials like cotton wastes) make suitable substrates. Traditional preparation of the substrate is limited to tying the straw into bundles before soaking in water for 24 to $48 \mathrm{~h}$. The soaked straw is piled into heaps about $1 \mathrm{~m}$ high which are inoculated with spent straw from a previous crop. In less than one month, a synchronised flush of egg-like sporophores appears. These immature sporophores (in which the universal veil is intact and completely encloses the immature sporophore are sold for consumption just like the young sporophores ('baby buttons') of Agaricus (though oyster and shiitake mushrooms are sold mature). Improvements in $V$. volvacea cultivation have been limited due to its low biological efficiency (that is, low rate of conversion of growth substrate to mushroom fruit bodies), although improved fruiting was observed on cotton waste supplemented with sodium acetate. It being suggested that treatment of the cultivation substrate with this chemical improved the availability of nutrients for vegetative hyphal growth, particularly the proliferation of hyphal branching (Hou et al., 2017) of the sort that promotes sporulation in saprotrophs (Moore et al. 2008).

Other issues that need to be addressed in Volvariella volvacea cultivation are its sensitivity to low temperatures, which makes it difficult to maintain a good quality in post-harvest storage. Even in cold storage the crop turns brown and autolyses within 2-3 days. Most important of all, though, is the 
ambiguous sexuality pattern of $V$. volvacea that has restricted the breeding of improved strains. This latter point is explored further in section 13, below.

Lentinula edodes was traditionally grown on wood logs (Chang \& Hayes 1978; Chang \& Miles 1989). This method has been replaced by artificial log cultivation that uses heat-treated substrates based on sawdust enclosed in plastic bags ('bag-log cultivation'). The main advantages of this method are the short time to complete a crop cycle and the higher yields (Sánchez, 2004). However, in an attempt to increase mushroom yields in log wood and/or sawdust-based substrates, other fruiting stimuli have been studied. A pulsed high-voltage stimulation technique has been applied as an electrical stimulation to accelerate fruiting and increase yield in woody substrates used for mushroom cultivation (Ohga et al., 2004; Takaki et al, 2009). Takaki et al. (2014) applied electrical stimulation to a sawdustbased substrate of Lyophyllum decastes and natural logs, in which Lentinula edodes, Pholiota nameko, and Naematoloma sublateritium were grown, and observed fruit body induction and hydrophobin release from the vegetative hyphae (in Lentinula edodes) one day after the stimulation. It was suggested that the pulsed electric field affects the hyphae through an electrostatic force, increasing the hypha activity (Takaki et al., 2014).

Current methods used in commercial production of Ganoderma, include wood log, tree stump, sawdust bag, short blocks of basswood (from the tree genus Tilia, known as Lime or Linden in Europe) and bottle procedures (Hapuarachchi et al., 2018). Mycelial growth, fruiting and development of fruit bodies require specific nutritional factors and environmental conditions (Zhou et al., 2017). In particular, Ganoderma is very sensitive to light/dark conditions; light inhibits mycelial growth, but low light levels can promote fruiting (Zhou et al., 2012, 2017; Montoya et al., 2018).

\section{THE FORMAL TERMINOLOGY OF DEVELOPMENTAL BIOLOGY}

Development is formally defined as the process of change and growth within an organism during the transition from embryo to adult. This definition immediately creates a major challenge for any mycologist interested in development, because it specifies 'embryo', an inevitable result of the fact that most developmental biologists deal with animal systems. Fungi do not have embryos. In fact, fungi are modular organisms in which the multicellular structures (especially fungal sporophores like mushrooms, etc.) are appendages of their mycelium, they are NOT individual organisms. This is a feature that fungi share with clonal corals and vegetatively-propagated plants and algae (Harper et al., 1986; Andrews, 1995; Monro \& Poore, 2004). The most succinct description of the modular growth form as it applies to fungi (Andrews, 1995) notes that modular organisms are:

'...characterised by an iterative, indeterminate mode of growth; internal age structure; localised rather than generalised senescence; cellular totipotency; and passive rather than active mobility.'

This quotation describes the fungal mycelium, Andrews (1995) goes on to point out that:

'...differentiation of a few basic cell types gives rise to multicellular complexes associated with foraging, reproductive, survival, or dispersal activities.' And finally: '...morphological plasticity of fungi is analogous to but surpasses that of other modular creatures such as the benthic invertebrates and plants. For instance, in response to environmental signals, fungi can vary the timing, extent, and mode of differentiation; interconvert among different growth forms; and decouple the sexual and asexual phases of the life cycle... (Andrews, 1995)'.

We suggest that we compare fungal development with animal development and borrow those aspects of the concepts that apply to animals that suit our mycological purposes.

Despite what is said above, early development of something like a mushroom looks much like an embryonic process (Fig. 1), and it is clear from images like this that we gain a lot by being able to use the vocabulary of animal embryology, For example: the series of images shown in Fig. 1 clearly show 
development of the basic body plan of a mushroom; the pattern formation that demarcates the main tissues and organs obviously takes place at a very early stage because the veil, cap, gills, stem and stem base are all clearly established in a tiny structure barely $1 \%$ the size of the final mature mushroom (just like an embryo!).

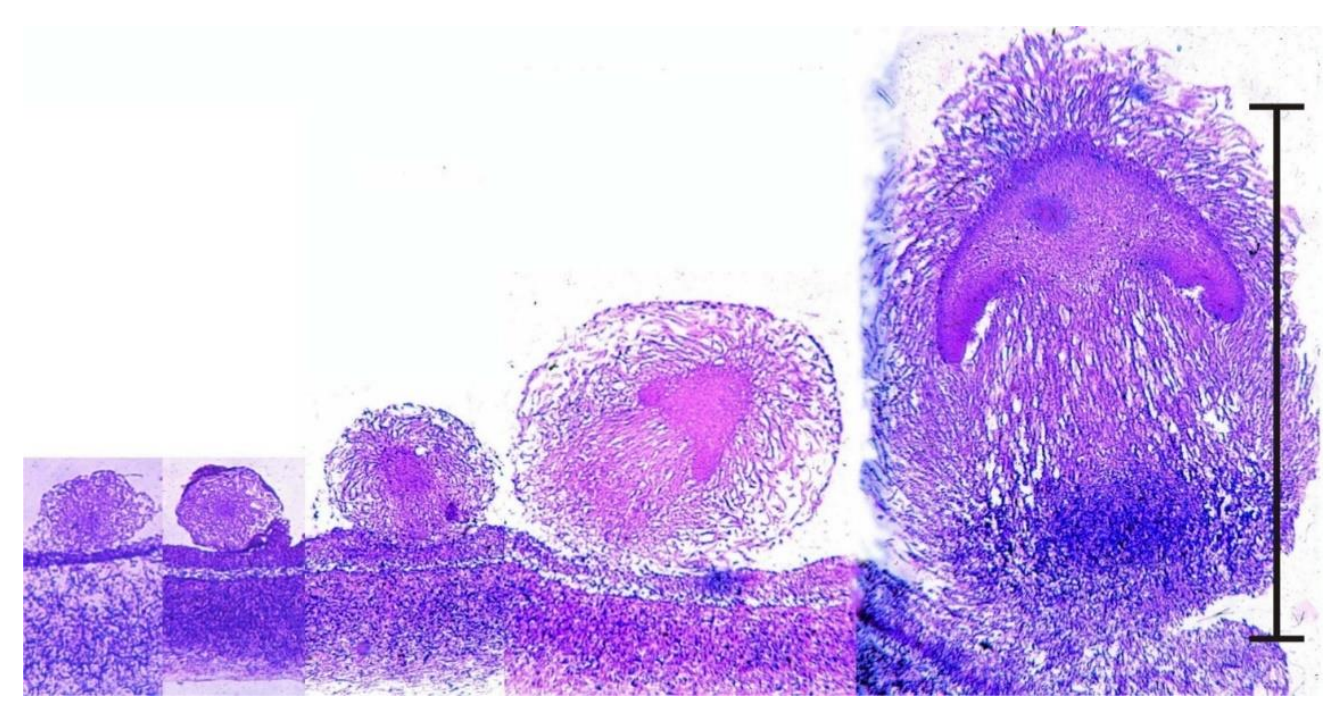

Fig. 1. Early development of something like a mushroom looks very much like an embryonic process (scale bar $=1 \mathrm{~mm}$ ); but remember that fungi are clonal organisms and these objects are sporophores, and many of them may be produced by an individual mycelium over an extended period of time. These images are photomicrographs of light microscope sections of successive stages in the very early development of the sporophore of the ink cap mushroom, Coprinopsis cinerea. The mature sporophore is approximately $100 \mathrm{~mm}$ tall, so this sequence covers just the first $1 \%$ of its developmental programme. The sections have been stained with the Periodic Acid-Schiff reagent, which stains polysaccharide accumulations bluepurple; in this case the polysaccharide, identified by other analyses, is glycogen, which goes through a cycle of accumulating first in the stipe base before being translocated to the cap tissues. The object at extreme left is a large hyphal tuft, at second left is an initial (it shows some internal compaction and differentiation and can become either a sclerotium or a sporophore, depending on environmental conditions). Note that the third section is obviously differentiated into cap-like and stem-like structures, even though it is only $300 \mu \mathrm{m}$ tall, and this is even more evident in the fourth section $(700 \mu \mathrm{m}$ tall), which has young gills but no gill cavity. At extreme right is a $1.2 \mathrm{~mm}$ tall sporophore primordium, in which the basic 'body plan' of the mushroom is complete with clear demarcation into veil, pileipellis (= cap epidermis), cap, gills (with the beginnings of an annular gill cavity), and stem (with a distinct stem basal bulb which features the heavy accumulations of glycogen).

Remember that the main eukaryotic kingdoms are thought to have separated in evolution at some single-cell level (Moore, 2013a), so the three eukaryote groups that make multicellular structures became distinct from one another long before the multicellular grade of organisation was established in any of them. The three kingdoms evolved the mechanisms and mechanics of multicellularity quite independently. There is no reason to expect that the mechanisms that have developed will have anything in common. They will, of course, share all those features that clearly categorise them as eukaryotes, but there is no logical reason to expect that these three Kingdoms will share any aspect of their multicellular developmental biology.

For the most part, the many kingdom-specific differences in cell biology between animals, plants and fungi result in very different emphases in the way these groups manage their developmental biology. Even in lower metazoans, a key feature of embryo development is the movement of cells and cell populations to remodel an initially unstructured group of cells (Leptin, 2005; Williams \& Solnica-Krezel, 2017); evidently, cell migration (and everything that controls it) must play a central role in animal morphogenesis. In contrast, plant cells are encased in walls and have little scope for movement, so 
their changes in shape and form depend on control of the orientation and position of the mitotic division spindle and, consequently, the orientation and position of the daughter cell wall which forms at the spindle equator (ten Hove et al., 2015).

Fungi are also encased in walls; but two particularities of their basic structural unit, the hypha, result in fungal morphogenesis being totally different from plant morphogenesis. These are that:

- extension growth of a hypha occurs only at its apex; and

- cross walls form only at right angles to the long axis of the hypha (see Chapter 4 in Moore et al., 2020).

The consequence of these features is that no amount of cross wall formation ('cell division') in fungi will turn one hypha into two hyphae. To proliferate a hypha must branch, and to form the organised structure of a tissue, new hyphal apices must be formed to initiate branches and the position at which the branch emerges from its parent hypha and its direction of growth must be precisely controlled. This is the crucial feature that makes fungal developmental morphogenesis fundamentally distinct from that of both animals and plants. Fungal morphogenesis depends on the placement of hyphal branches.

Comparison of the way similar functions are controlled in different organisms can reveal whether and how different cellular mechanisms have been used to solve common developmental demands (Meyerowitz, 1999). Although, of course, fungi do not feature in such discussions. We intend to feature them, and we will do this by showing some of the experiments and observations that have led to the understanding we currently have of fungal multicellular development. This will involve delving into some of the older literature and will also show how simple experiments and quantitative observations can contribute to important inferences about the fundamental processes involved in fungal developmental biology that provide the sound foundation on which molecular biology and genomics can build.

\section{THE OBSERVATIONAL AND EXPERIMENTAL BASIS OF FUNGAL DEVELOPMENTAL BIOLOGY}

The mushroom is a spore-dispersal organ that is umbrella-shaped to protect the spore-release process from rain (hydrophobic interactions with a droplet of watery fluid liberate basidiospores, this can't happen in the rain). The spores form on cells in a hymenium that lines the under surface of the mushroom cap. The surface area covered by hymenium is increased by the under surface of the cap being divided into vertical plates (the gills), closely-packed tubes (pores), or tooth-like spikes. Increasing the surface area covered by hymenium has selective advantage because it increases the reproductive capacity of the structure (see Chapter 10 in Moore et al., 2020). The mushroom form has evolved independently several times in different fungal phylogenies (Varga et al., 2019).

The geometrical proportions of the stem (short and stocky, or long and slender) vary with the demands of its support function: large caps require more substantial stems, etc. But they also vary with the demands of the ecology and habitat of the species: short stems may be appropriate in species that form sporophores on bare soil, but those that characteristically come up into plant litter or amongst heavy plant cover may depend on tall stems to lift the cap into an air flow. As well as the geometry, mechanical considerations also determine the anatomy of the sporophore.

- Short and stocky stems tend to be constructed of solid tissue when mature. Like an architectural weight-bearing column; its compression transmits the weight of the structure above to other structural elements below.

- Tall and slim stems tend to be anatomically hollow cylinders at maturity because such a structure performs better than a solid column when under lateral stress. 
The stem, however, has more to do than simply support the cap physically; it must also support the cap physiologically. All the nutrients and all the water the cap needs to shape itself and produce its crop of spores are supplied from the mycelium and must be translocated through the stem.

The anatomical pattern that we recognise as 'a mushroom' results from differential growth and morphogenesis of the component tissues of the developing mushroom (Fig. 1), and there are a wide variety of differential growth patterns that generate the tremendous morphological diversity evident among the sporophores of these higher fungi (Watling \& Moore, 1994). We will discuss the cellular details of development in the ink cap mushroom now called Coprinopsis cinerea as our model.

\section{COMPETENCE AND REGIONAL PATTERNING}

Production of a multicellular structure is an aspect of mycelial differentiation and the mycelium must have access to the necessary resources. The formal description is that the mycelium must be competent to undertake production of a multicellular structure. In practical terms this means that the exploratory mycelium has found and captured sufficient of its substratum to have internalised, in the form of accumulated nutritional stores, adequate supplies for all the synthetic processes involved in further development and morphogenesis. The essential point is that nutrients are no longer outside the hyphal system and potentially available, but they are inside the hyphal system and immediately available. This change in balance results in shifts in some of the regulatory circuits that then lead to cell and tissue differentiation.

The flow chart of Fig. 2 summarises the processes involved in development of sporophores and other multicellular structures in fungi and shows that there is also a genetic component to competence. Vegetative compatibility systems and mating type factors can both contribute to mycelial interactions (Chapters 8 and 9, respectively, in Moore et al., 2020), the latter resulting in formation of a sexually compatible mycelium, which is competent to make sporophores.

As is indicated in this flow chart, the onset of multicellular development is usually signalled by some sort of disturbance that causes a check or restraint to normal (exploratory, invasive) vegetative growth. This restraint might be imposed by a nutritional crisis: perhaps the substrate becomes exhausted of nutrients (of many or even only one or two crucial ones; the preferred carbon source and the preferred nitrogen source, for example). This does not mean that the mycelium is starving, because the mycelium has absorbed and stored many nutrients, but it does mean that the balance of nutrient supply is changed, and this will result in a change of regulatory pattern within the hyphae.

Other major signals that have been the subject of numerous laboratory experiments are temperature shocks, light exposure, edge encounters and physical injury, all of which can also be related to natural events in the normal habitat. Many of the Basidiomycota require a drop in temperature to form sporophores, which may reflect their adaptation to seasonal temperature fluctuations. Response to illumination patterns may reflect response to day light or day length, or even a growth habit in which the mycelium grows through a dark substratum (like a litter layer, pile of plant debris or herbivore dung, etc) to eventually emerge at a light-exposed surface. A 15-minute exposure to blue light induces hyphal knot formation in Coprinopsis cinerea mycelia grown on low-glucose media but not in mycelia grown on high-glucose media. Transcriptome analysis revealed a two-stage response to illumination. Several genes are upregulated by $1 \mathrm{~h}$ of blue light exposure in the mycelial region where the hyphal knot will be developed; this upregulation is not influenced by nutrients. These genes are thought to be essential for induction, but not sufficient for development of the hyphal knots. In the second expression stage, genes involved in the architecture of hyphal knots are upregulated after a 10-16 h blue light exposure if the mycelia are cultivated on low-glucose media (Sakamoto, 2018; Sakamoto et al., 2018). 


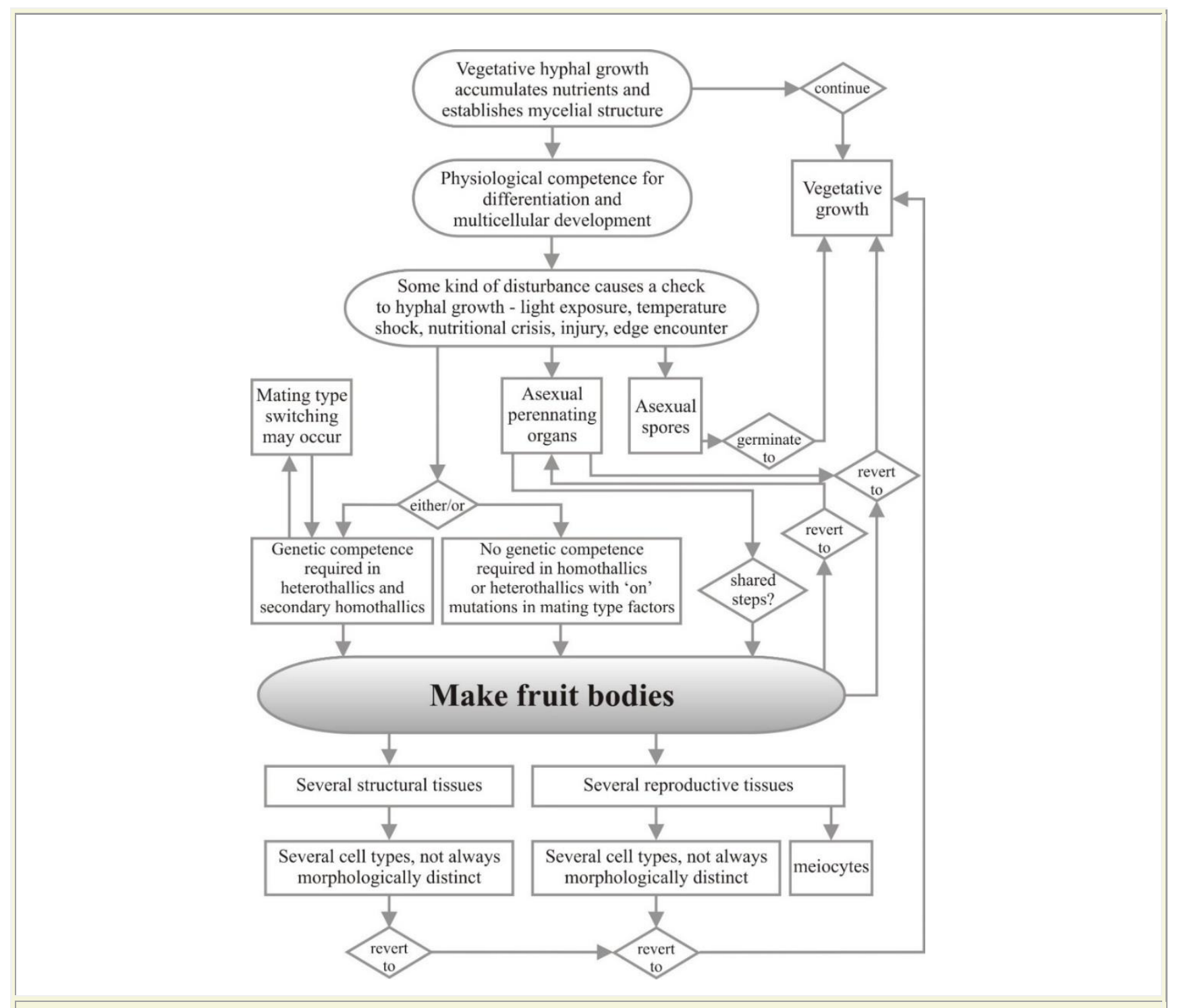

Fig. 2. Flow chart showing a summarised view of the processes involved in development of sporophores and other multicellular structures in fungi. Modified from Moore \& Novak Frazer, 2002.

Sporophores do not arise from single cells, although this was believed to be the case for many years in the 20th century. Rather, initiation of multicellular structures like sporophores and sclerotia involves aggregation of cells from different sources as a result of hyphal congregation that is the direct result of the most fundamental change in hyphal growth pattern: namely that in vegetative mycelia hyphae show negative autotropism (hyphal tips grow away from each other) whereas to form a condensed multicellular tissue component hyphal tips must show positive autotropism and grow towards each other (Matthews \& Niederpruem, 1972; Waters et al., 1975; Van der Valk \& Marchant, 1978).

Unlike animal embryos, fungal multicellular structures evidently do not normally consist of a population of cells which are the progeny of a single progenitor but are assembled from contributions made by a number of co-operating hyphal systems. Indeed, in a few cases sporophore chimeras have been observed. Kemp (1977) described how mushrooms of 'Coprinus' formed on horse dung collected in the field but incubated in the laboratory could consist of two species (then identified as Coprinus miser and $C$. pellucidus but now assigned to different genera and named Parasola misera and Coprinellus pellucidus). The two have distinctively different basidiospore morphologies and the hymenium comprised a mixed population of basidia bearing the two different sorts of spores, so the chimera extended throughout the sporophore. 
Generally speaking, the most highly differentiated cells occur on the outside of the tissue blocks that make up fungal multicellular structures (Williams et al., 1985). Thus, major morphogenetic events in fungi, like those in animals and plants, are associated with tissue surfaces and their 'epidermal' layers of cells that separate adjacent tissues. As the adult tissues are demarcated in even the earliest sporophore initials (as shown in Fig. 1), fungi are like animals and plants in having a basic 'body plan' which is established very early in development. The pattern of tissue distribution that makes up the 'body plan' is established sequentially by the processes of regional specification, cell differentiation, and cell co-ordination. It is likely that all of these processes are orchestrated by morphogens and/or growth factors.

\section{THE COPRINOPSIS MUSHROOM: MAKING HYMENIA}

In Coprinopsis cinerea, differentiation of the gills (on which the hymenium will be formed) becomes evident in a region corresponding to the boundary between stem and cap tissues before any annular cavity (Fig. 1). The gills arise as vertical ridges of small, closely packed hyphal branches, and as this wave of differentiation moves through the tissue towards the outer surface of the cap it leaves behind two organised plates of columnar cells which constitute the primordial hymenia of adjacent gills separated by a developing gill cavity.

The central tissues of the first-formed (primary) gills remain intimately connected by interwoven hyphae to the periphery of the stem for a considerable time, becoming freed only in well-developed primordia. From this early stage right through to final maturation of the mushroom, developmental changes proceed along two major vectors: from inner edge of the gill (that is, the edge closest to the stem) towards the outer edge (that closest to the exposed surface of the cap) and from the cap margin towards the cap apex (Rosin \& Moore, 1985a).

In the mushroom cap of Coprinopsis cinerea the gills are described as developing parallel to one another and retain this arrangement throughout development; strictly speaking, they are arranged along the radii of the cap, but they are so thin and numerous as to appear parallel when small segments are examined. The gill surface is the hymenium composed of three highly differentiated cell types: basidia (the cells on which spores are formed; cystidia (large inflated cells); and paraphyses, which are sterile secondary cells, though this description unintentionally diminishes their importance as they eventually form a pavement that provides most of the mechanical structure of the mature gill.

All these cells arise as hyphal branches from the central layer of the gill, the trama, the constituent cells of which maintain an open and basically hyphal structure. Those '...ridges of small, closely packed hyphal branches...' that form the first hymenium of $C$. cinerea are mostly young basidia (often called protobasidia), which will eventually undergo meiosis (Fig. 3) and produce basidiospores, with cystidia scattered amongst them.

Cystidia arise as the terminal compartments of unbranched tramal hyphae (Fig. 3); from the very first, cystidia are much larger cells. They span the gill cavity, connecting the hymenia of two different gill plates and serve a mechanical function, spreading the tension loads caused by cap inflation through all the gills (discussed below). Only about $8 \%$ of the tramal hyphal branches become cystidia; the rest become protobasidia (Horner \& Moore, 1987).

Paraphyses originate as branches from the hyphal cells immediately beneath the basidia, and the branches force their way into the basidial layer, inflating as they do so (Fig. 3). About $75 \%$ of the paraphyses have inserted by the time meiosis is completed, the rest insert at later stages of development. In contrast, basidia did not increase in number once paraphysis insertion had started (Rosin \& Moore, 1985b).

Evidence for local control of morphogenesis has been obtained from a statistical comparison of the distributions of cystidia on adjacent hymenia in the Coprinopsis mushroom (Horner \& Moore, 1987), 
which demonstrated an inhibitory zone around each cystidium that reduced the probability of another cystidium arising in the same hymenium in its immediate vicinity. This zone had a radius of about 30 $\mu \mathrm{m}$ and was strictly limited to the hymenium of origin. It may be that cystidium formation is dependent on a patterning process similar to the activator-inhibitor model (also called the morphogenetic field model) developed by Meinhardt \& Gierer (1974) and Meinhardt, 1976, 1984).



Fig. 3. The differentiating hymenium of Coprinopsis cinerea in light micrographs of sectioned tissue. A (scale bar: $20 \mu \mathrm{m}$ ), B and C (scale bars: $5 \mu \mathrm{m}$ ) show the hymenium of a primordium 1 to $2 \mathrm{~mm}$ tall (similar to the extreme left photograph of Fig. 1). This hymenium consists of a closely packed layer of young basidia, with occasional large, but still young, cystidia. Branches from sub-basidial cells that become paraphyses are the more densely-stained hyphal tips, forcing their way into the basidial layer. Images D, E (scale bars: $10 \mu \mathrm{m}$ ) and $\mathrm{F}$ show a later stage in which paraphyses have begun to inflate. Their connection to sub-basidial cells is still very clear. F shows that the pileipellis ('epidermis' of the cap) is a layer of closely packed cells, like the hymenium. However, the cap flesh is a very open tissue with large intercellular spaces, and the same is true of the gill trama (the gill flesh) in which the hyphal nature of the tissue is clear. Photomicrographs by Isabelle V. Rosin; illustration modified from Moore (1998a).

The descriptions we have just given illustrate a number of developmental control events that indicate exquisite regulation of morphogenesis in fungal sporophores.

- First, these differentiations are occurring in the gill tissues of the cap while an alternative set of differentiations are happening in the stem tissues, just a few hundred $\mu \mathrm{m}$ distant. 
- Second, these are fungal tissues, so the cellular elements involved are hyphal branches composed of hyphal compartments bounded by dolipore septa. In vegetative growth on the surface of an agar medium, leading hyphae of this dikaryon produce branches at about $73 \mu \mathrm{m}$ intervals, but as you can see from Fig. 3 the branching frequency at the hymenium is ten or twenty times greater than that.

- Third, there are at least four cellular differentiation pathways on display here: undifferentiated hyphae of the trama, basidia, cystidia and paraphyses (we'll refer to a fifth cell type, cystesia, below); all the cell types mentioned arise as branches from the tramal hyphae, yet despite their relationship as sister branches of the same hyphal system, cells separated only by a dolipore septum clearly follow totally different pathways of differentiation.

- Fourth, all of the cells that make up the hymenium are formed from hyphal branch tips that stop extending and differentiate. Cessation of extension is coordinated across the entire population of branches so that the surface of the hymenium ends up as a uniform layer.

- Fifth, the direction of extension of the hymenial branches is also uniform; look at Fig 3A and you'll see hundreds (in life, hundreds of thousands) of branches from the tramal hyphae all growing 'upwards' (in the image) to make one hymenium layer, and just a few $\mu \mathrm{m}$ distant from these an equal number of branches from the same tramal hyphae all growing 'downwards' to make the other hymenium layer of the same gill.

- Finally, there is a matter of timing; the first population of branch tips become protobasidia and cystidia, and after they have been specified, branches emerge from the first cell (hyphal compartment) beneath each protobasidium and specifically grow into and between the established layers of protobasidia to create the paraphyseal pavement. This process is also coordinated in time and in position across a large population of independent hyphal branches.

The hymenium of Agaricus bisporus adds another interesting example by using basidia in two different ways: (i) for their primary purpose of sporulation, and (ii) to serve as structural members. Although the Agaricus hymenium is said to contain sterile cells, Allen et al. (1992) found that protobasidia with single fusion nuclei were in the overwhelming majority throughout the life of the mushroom, right through to senescence. In most protobasidia meiosis was arrested in meiotic prophase I and the arrested protobasidia were kept in that state so they could serve as structural elements in the hymenial layer.

\section{AGARICS MAKE GILLS AND POLYPORES MAKE TUBES}

There is a fifth cell type in the hymenium of Coprinopsis cinerea, and its origin illustrates yet another phenomenon found in other organisms. At early stages in growth of the cystidium across the gill cavity the cell(s) with which the cystidium will come into contact in the opposing hymenium are indistinguishable from their fellow protobasidia. However, when a cystidium comes firmly into contact with the opposing hymenium, the hymenial cells with which it collides develop a distinctly granular and vacuolated cytoplasm. This suggests a contact stimulus aborting continuation of basidial differentiation in those cells and setting in train an alternative pathway of differentiation leading to an adhesive cell type (called the cystesium (Horner \& Moore, 1987). The cystidium-cystesium adhesion is very strong, being based on joint wall synthesis. The functional explanation of such a singularly strong adhesion starts with the observation that when first formed the primary gills of Coprinopsis cinerea appear as convoluted, folded plates (Fig. 4).

For such convoluted gills of Coprinopsis cinerea to end up 'parallel', it is envisaged that as the cap expands the gills are tensioned into the regular parallel arrangement (shown in Fig. 3). The process is accomplished through the anchorages provided by the connection of primary gills to the stem and by cystidium-cystesium pairs acting as tension elements, interconnecting gill plates into a fully tensioned structure around the stem as cap expansion pulls the gills into shape. The tension is a geometrical consequence of the way the mushroom matures. 
The primordial cap in Coprinopsis encloses the top of the stem with the gills arranged as vertical plates radially around the stem. Simple measurements show that as typical mushroom primordia of $\mathrm{C}$. cinerea grow from one to $34 \mathrm{~mm}$ in height, the circumference of the stem increases by a factor of 9 while the outer circumference of the cap increases by a factor of 15 (Moore et al., 1979). As the primary gills are connected to both of these surfaces, they will inevitably be stretched by the outer surface being increased more than the inner, and the regular distribution of strongly adhering cystidium-cystesium pairs will act as tension ties communicating and equalising these tension forces through all of the gills (Chiu \& Moore, 1990a).

Fig. 4B also shows that embryonic gills of Volvariella are convoluted in very young primordia, too, but quite differently from the coprinoid-type. The overall developmental programme for all agaric gills (using the word 'agaric' in the widest sense to mean any 'mushroom' with gills) seems to be that primary gills arise as ridges on the lower surface of the cap, projecting towards the stem, and secondary and tertiary gills are added whenever and wherever space becomes available.

Generation of additional gills occurs by bifurcation of an existing gill either from one side or at the free edge, or by folding of the hymenium layer near or at the roots of existing gills. Application of these 'developmental rules' (particularly the 'whenever and wherever space becomes available' rule) inevitably gives rise to the sinuous (= labyrinthiform) gill pattern illustrated in Fig. $4 \mathrm{~B}$ as a normal transitional stage to the regularly radial pattern so often seen in mature mushrooms.
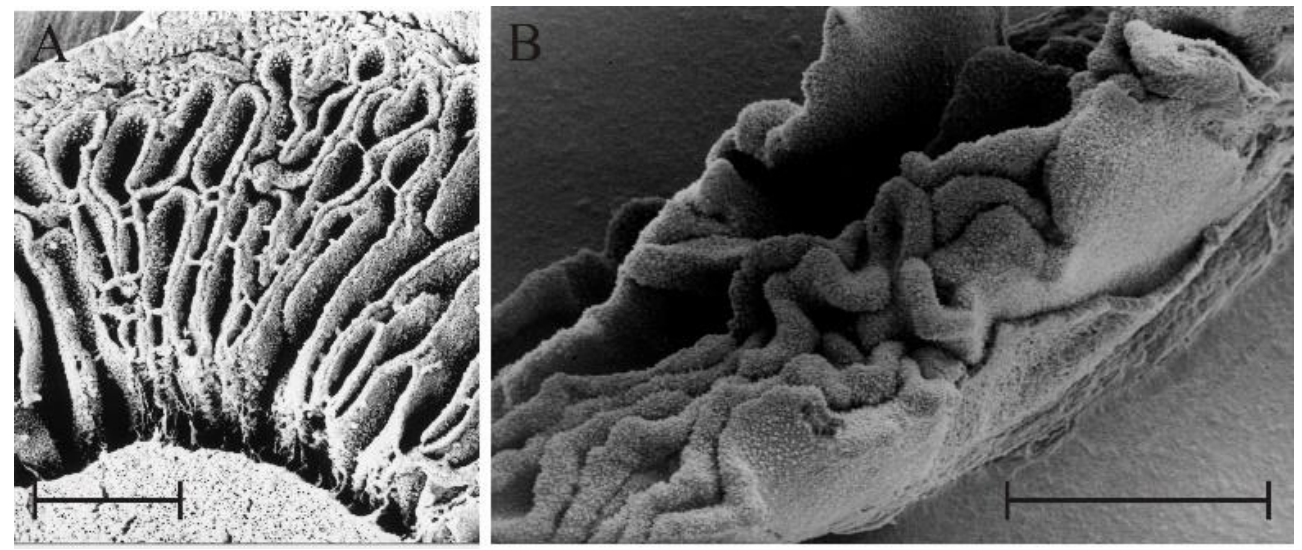

Fig. 4. 'Embryonic gills' in both Coprinopsis cinerea (A) and Volvariella bombycina (B) are clearly seen to be convoluted in these scanning electron microscope preparations. The scale bars $=0.5 \mathrm{~mm}$ so these are pieces of tissue from very small mushroom primordia, just a few $\mathrm{mm}$ in overall size from organisms that produce mature mushrooms several $\mathrm{cm}$ in size. Photomicrographs by Prof. S.-W. Chiu, Chinese University of Hong Kong. Illustration modified from Moore (1998a).

Transformation of the convoluted gills into regularly radial ones is accomplished by cell inflation in the gill trama of Volvariella. The mature hymenium of Volvariella (Fig. 5) is a layer of tightly appressed cells, and the trama of the broken gill shown in Fig. 5 is full and crowded with greatly inflated cells. Reijnders (1963) and Reijnders \& Moore (1985) emphasised the role played by cell inflation in driving developmental events in fungal structures, so it doesn't take much imagination to realise that inflation and growth of tramal cells in gills enclosed by the hymenial 'epidermis' will generate compression forces which will effectively inflate, and so stretch, the embryonic gills to form the regularly radial pattern of the mature cap. Thus, in this case the gill is inflated into shape and, in structural engineering terms, the mature gill is a stretched-skin construction which owes its mechanical strength to the combination of compression in the trama and tension in the hymenium (Chiu \& Moore, 1990b).

The direction of gill development has been established for conventional agaric fungi by placing ink marks at measured intervals with minimum disturbance to the young sporophore of Volvariella (Chiu \& 
Moore, 1990b) and observing what happens to them as the sporophores mature. Ink marks placed near the cap apex remained close together whereas marks originally close together in the mid regions of the outer surface of the cap became widely separated (and were made more diffuse) by subsequent growth. Also, ink marks placed on the cap margin and those placed on the free edges of the gills remained at the margin or the free edge, demonstrating that:

a. the greatest contribution to cap expansion occurred in an annulus some way in from the margin and not extending to the apex;

b. the free edges of the gills remained intact and were not replaced;

c. the margin of the cap was similarly not replaced though its circumference increased.

It's a simple experiment but it has decisive implications. The crucial observation is (b) which shows that the gill edge is fully differentiated; it is not a growth site, the same hyphal tips that were located at the gill margin in the immature sporophore remained at the gill margin throughout maturation. Thus, it follows that individual gills of Volvariella do not grow by extension at their free edge, and from (c) that the cap margin is not a growth centre for radial extension. Similar experiments have been done with sporophores of Pleurotus pulmonarius: the originally-marked gill margins remained intact although further growth of the cap periphery involved production of entirely new (unstained) tissue which extended the cap periphery radially outwards. Evidently, these gills also grow at their root. However, in $P$. pulmonarius the cap margin proved to be a region of active growth (observations of Carmen Sánchez, illustrated as Fig. 6.42 in Moore, 1998a).
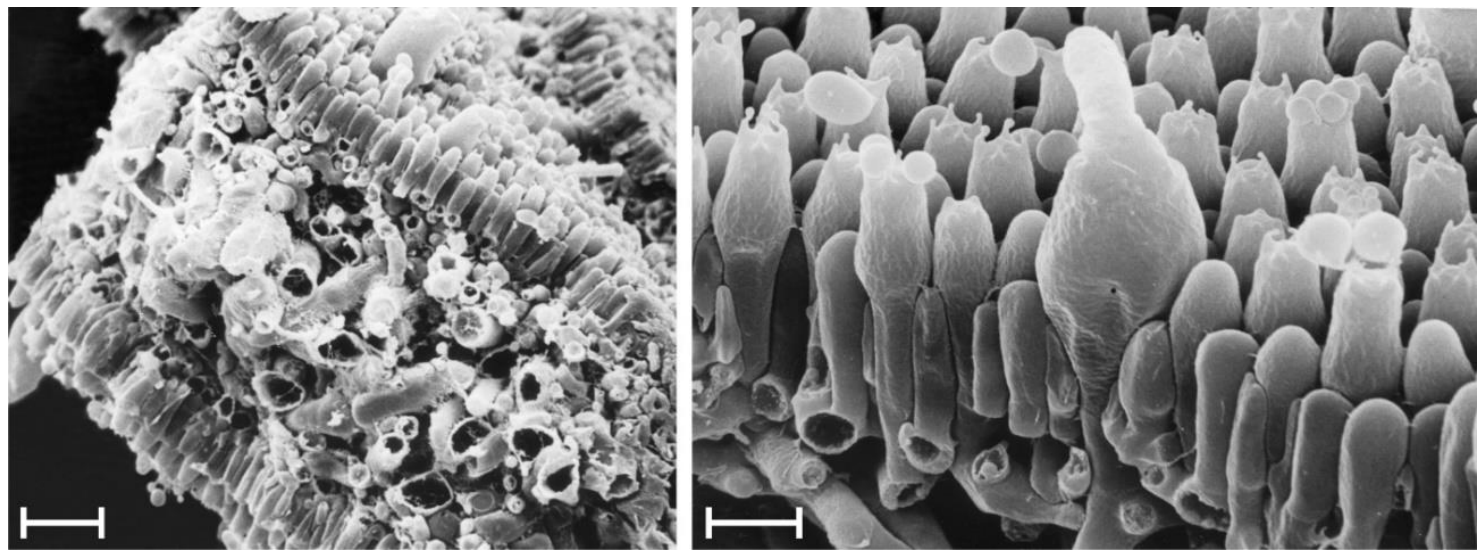

Fig. 5. The mature gill of Volvariella bombycina in scanning electron microscope images. Left is a view of the exposed trama of a gill broken whilst frozen (scale bar $=20 \mu \mathrm{m}$ ), and the right hand image is a magnified view of the hymenium (scale bar $=5 \mu \mathrm{m}$ ). Note that the hymenial cells are closely packed and interlocked to form a coherent layer, like the tightened skin of a balloon, stretched over a gill trama which contains a mass of greatly inflated cells. The gill is inflated into shape and, in engineering terms, is a stretched-skin construction which owes its structural strength to the combination of compression in the trama and tension in the hymenium. Photomicrographs by Prof. S.-W. Chiu, Chinese University of Hong Kong. Illustration modified from Moore (1998a).

The inevitable conclusion is that agaric gills extend in depth by growth at their roots and by insertion of hymenial elements into their central and root regions. The cap extends radially by insertion of new hyphal branches alongside the older hyphae in a broad region behind the margin. Thus, the hyphal tips which form the cap margin when it is established at the very earliest stage of development remain at the margin. They do not continue to grow apically to extend the margin radially, nor are they overtaken by other hyphae; instead they are 'pushed' radially outwards by the press of fresh growth behind, and they are joined by fresh branches appearing alongside as the circumference of the margin increases. 
As we've noted, the young Coprinopsis mushroom has a different geometry from a more conventional 'mushroom' shape because the primordial cap completely encloses the top of the stem, and primary gills, from their formation, have their inner (tramal) tissue in continuity with the outer layers of the stem. Both stem and cap circumferences increase by a factor of around ten but if the (stem) surface to which the gills are attached is expanding, then the gills would be expected to be prone to widening during maturation. However, mature gills are narrow so this tendency to widen as the circumference increases must be compensated by increase in number of gills. How this is accomplished is indicated in images like Fig. 6 , which show formation of a new gill cavity and its bounding pair of hymenia within the trama of a pre-existing primary gill. The Y-shaped gill structure is the crucial observation (Rosin \& Moore, 1985a). These Y-shaped gill structures are oriented exclusively as though the fork in the $Y$ originates at the level of the stem surface and moves outwards towards the outer surface of the cap.

So, there is a clear indication that gills in Coprinopsis develop radially outwards, their roots extending into the undifferentiated hyphae of the cap tissue. It is believed that there is a formative element at the fork in the $Y$ (called a gill organiser) in the vicinity of each gill arch (that is, at the apex of each gill space) which is responsible for the progression of the gill morphogenetic field outward, away from the stem into the steadily replenished undifferentiated cap tissue (for explanatory diagrams see Fig. 13.21 in Moore et al., 2020).

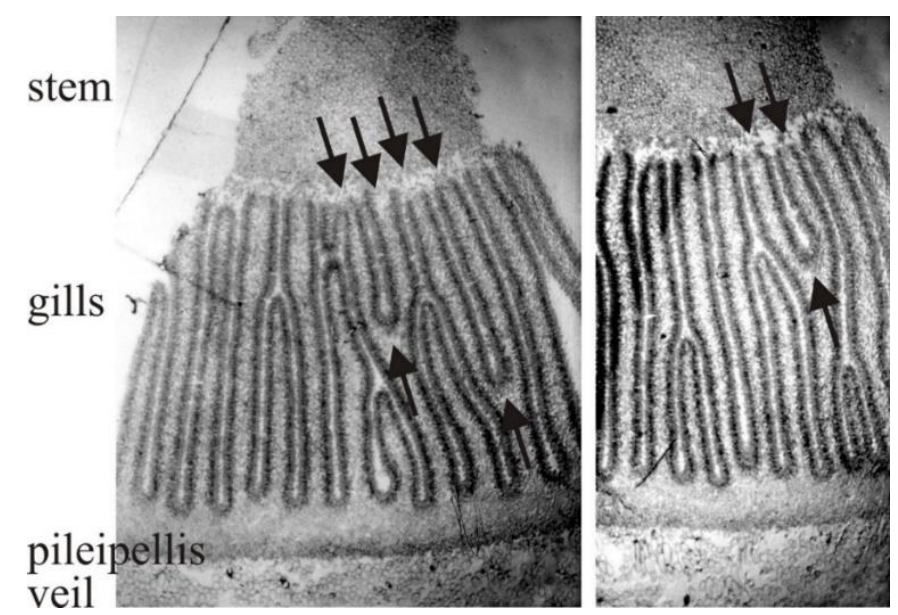

Fig. 6. Two transverse sections of a mushroom cap of Coprinopsis cinerea. Stem tissue is at the top. All of the gills which have their tramal tissue continuous with the stem are primary gills. Note that two of these in one section and one in the other show a Y-shaped profile, in which both arms of the $Y$ are still connected to the stem (arrows). This indicates that primary gills proliferate by formation of a new gill space within the trama of a pre-existing primary gill. Light micrographs by Isabelle V. Rosin. Illustration modified from Moore (1998a).

This set of observations gives presumptive evidence for two classic components of theoretical morphogenesis (Rosin \& Moore, 1985a):

- On the one hand we can hypothesise radial diffusion of an activating signal which assures progression of the gill pattern of morphogenesis radially;

- on the other hand, we may have tangential diffusion of an inhibitor which prevents formation of new organisers until the extent of the tissue domain exceeds the effective range of the inhibitor; at which stage a new organiser can arise in response to the radial activating signal.

Interaction between the presumed gill organiser activator and the presumed gill organiser inhibitor is all that is necessary to control gill spacing, gill number, gill thickness, and the perfectly radial orientation of the gill field. The characteristic general arrangement of the stem, gills and cap which is the essential mushroom, constitutes the basic body plan of gilled fungi. It is most significant that the growth vector across the width of the gill is directed away from the stem in all species in which this 
point has been examined implying that the gill grows at its root and not at its margin. Thus, the generalised interpretation is that all gills grow by extension at the root and not by growth at the free edge (Moore, 2013b).

For Coprinopsis and Volvariella, which are characteristic agarics, the developmental vector of the gills is directed away from the stem. The same also seems to be true for Pleurotus and Lentinula. However, outward growth of the cap margin was not the same as in Coprinopsis and Volvariella. In $P$. pulmonarius and $L$. edodes the margin proved to be a region of active growth. Presumably these different growth patterns are consequences of the suite of developmental strategies which create the morphogenetic distinction between these different sporophores. Certainly, the radially outward growth of cap tissue evident in Pleurotus pulmonarius is functionally similar to the lateral extension of the sporophore in the resupinate polypore Phellinus contiguus (Butler \& Wood, 1988). It seems, therefore, that Pleurotus maintains the ancestral direction of development for the structural tissue of the sporophore but abandoned the ancestral direction for development of the hymenophore. So, what of the pores of polypores?

Long ago Corner (1932) described how pores and dissepiments arose in an area on the underside of the young part of the cap of Polystictus xanthopus, a region he called the 'pore field'. Pores, of course, are the tubular holes which are lined with hymenium. The tissue which separates the pores is called the dissepiment. This word literally means a partition and is specifically assigned to the tissue between the pores of a polypore. Described in this way, it is implied that the pore is an entity in its own right. However, like the space between the gills of gilled-fungi, the pore is defined by the tissue around it; that is, by the pattern-forming growth and branching processes which take place in the hyphae of the dissepiments.

The pore is the place where the dissepiment does not grow. Corner (1932) defined the 'pore field' as an annulus near the margin on the underside of the cap, in which localised development of differentiating hyphal growth resulted in initiation of dissepiments as protruding ridges, which branched and united around non-extending areas. The latter became the pore bases. Corner also described a corresponding spine field in the hydnoid sporophore of Asterodon ferruginosus in which spines arose as localised areas of downwards growth 200-300 $\mu \mathrm{m}$ in diameter in which the hyphal tips were positively gravitropic (growing towards the centre of the Earth).

Constituent cells of the pore wall differentiated from mycelial hyphae. Hymenial elements were the first to differentiate, basidia and setae (a seta is a stiff hair-like sterile hyphal end with thick walls, projecting from the hymenium) arose directly from 3-day-old divergently-growing mycelium, setae differentiating first. In the pore bases this sparse discontinuous hymenium became more continuous as more basidia, and setae, differentiated in parallel with dissepiment growth (Butler, 1992a). Setae, basidia and dissepiment-building hyphae all differentiated on explants (Butler, 1992b).

Phellinus contiguus in nature produces a poroid sporophore which is flat on the substratum (that is, a resupinate sporophore), the usual substratum being the lower side of branches and twigs. Butler \& Wood (1988) described production of pores on colonies cultured in Petri dishes, 3-4 mm behind the colony margin. Sporophores formed in agar cultures of Phellinus contiguus were generally similar to naturally-occurring specimens; even the pore size and density were within the range found in nature. Butler (1995) found that sporophore formation could be promoted by one or more metabolic products found in extracts of $P$. contiguus cultures. The sporophore inducing substance has not been characterised.

Pores were formed only in inverted cultures (agar upwards). Disorganised growth of the tissue occurred in dishes with the agar lowermost, showing that some hyphae that contribute to sporophore construction are not positively gravitropic, though extension of the dissepiments clearly is. Butler (1988) distinguished two developmental processes in pore morphogenesis which she called island initiation and aerial fascicle growth (a fascicle is a little group or bundle of hyphae). 
Sporophore tissue arose as islands in the narrow initiation zone immediately behind the mycelial margin. New pores were formed by lateral extension from the island initials and the final pore density was not defined in the original pore field; rather, secondary pore formation occurred both by differential growth within thick dissepiment areas and by subdivision of primary pores. Continued growth of the dissepiment away from the supporting cap tissue delimited the pore. The edge of the dissepiment grows away from the underside of the cap, so the edge of the dissepiment grows vertically downwards. Clearly, then, pores extend at their free edge, but gills always extend at their root.

\section{THE COPRINOPSIS MUSHROOM: MAKING STEMS}

Mushroom stems are not as clearly divided into tissues as are caps, but they do show a level of differentiation and a distinct morphogenesis. Corner (1932) introduced hyphal analysis as a procedure to describe tissues of polypore sporophores and this is used in routine classification. Over the years several different types of hyphae and a range of tissue types have been described (Corner, 1966). Corner coined the terms monomitic, dimitic and trimitic to describe tissues consisting of one, two or three kinds of hyphae, and hyphae in these different categories have been referred to as generative (because they ultimately give rise to the basidia and directly or indirectly to all other structures), skeletal (with thick walls and narrow lumen, but lacking branching and septation) or binding hyphae (which have limited growth and irregular often repeated branching). Corner also introduced the terms sarcodimitic and sarcotrimitic to describe sporophores that have two or three types of hyphae (respectively) of which one is inflated and with thickened walls.

All these, remember, were first defined in polypore sporophores, but Redhead (1987) recognised such structures in a group of gilled fungi that includes the genera Agaricus, Collybia, Marasmius and Flammulina, so cellular differentiation in sporophore tissues is widespread. Indeed Fayod (1889) had already described the presence of narrow hyphae amongst the more easily seen cells of the sporophore tissues he examined. These were called 'fundamental hyphae' but they have not been used in identification in the way that the mitic system has in polypores; today we might call them something like 'embryonic stem cells', being undifferentiated vegetative cells able to differentiate into a diverse range of specialised cell types. Although there are many reports of the occurrence of differentiated hyphal cells in various parts of fungal sporophores it is the relative sizes of differentiated hyphal populations, their distributions and the way the populations change during development that are crucial to understanding cell and tissue functions and there is only one quantitative hyphal analysis, and this deals with the stem of Coprinopsis cinerea (Hammad et al., 1993a).

This study showed that any stem more than a few $\mathrm{mm}$ tall was dominated by highly inflated cells but two distinct populations of hyphae were identified and categorised as narrow hyphae, with crosssectional area less than $20 \mu \mathrm{m}^{2}$, and inflated hyphae, with cross-sectional area greater than $20 \mu \mathrm{m}^{2}$. Narrow hyphae always constituted a significant numerical proportion (23\% to $54 \%$ ) of the cells in transverse sections, although, being 'narrow', they only contributed $1 \%$ to $4 \%$ of the overall crosssectional area. Both narrow and inflated hyphae can be seen in sections of primordia only $3 \mathrm{~mm}$ tall. However, during stem elongation, the numerical proportion of narrow hyphae decreased as approximately $25 \%$ of them are recruited to the inflated category.

There was a progressive change in the distribution of inflated hyphae during maturation that resulted in increased cross-sectional area of inflated hyphae being accentuated in an annular region just over halfway across the radius. The geometrical consequences of this being (for explanatory diagrams see Fig. 13.23 in Moore et al., 2020):

- first, that the central core is torn apart (it is not expanding, but the tissue exterior to it is expanding so the centre must tear apart), leaving its constituent cells as a remnant around the inner wall of the lumen so created; 
- second, that the tissues in the zones outside the expanding annulus would be stretched and reorganised (they are not expanding, but the tissue interior to them is expanding, so outer tissue must be stretched).

This organised pattern of inflation generates the final morphology of the mature stem, converting a solid cylinder of hyphal tissue into a hollow tube, with a stretched-skin construction that gains structural strength from the combination of compression within the stem tissue and tension in its stretched outer tissues.

\section{CO-ORDINATION OF CELL INFLATION ALL THROUGH THE MATURING SPOROPHORE}

Most of the changes in shape during sporophore development in basidiomycetes depend on cell inflation; this is typically a slow process in young primordial stages and characteristically more rapid during late maturation. Local cell inflation during sporophore development has often been described and Reijnders (1963) showed that the different zones of sporophores enlarge proportionally, so that different tissues mature without being impeded, compressed or distorted by the growth of other parts. Such co-ordination of differentiation of cells in relation to their location is one of the most important general principles of animal and plant morphogenesis. It is thought to be based upon the migration through the developing tissues of pattern-forming morphogenetic factor(s) or signals.

If this is true for fungi, the nature of the signals is generally obscure, though in the larger sporophore primordia of Ascomycota and Basidiomycota the mechanism would need to operate over distances of many millimetres, a similar scale to animal and plant hormone fields. However, apparent 'coordination' could also result if developmental events are arranged in a consequential series such that one (secondary) event is only instigated by the initiation or completion of an earlier (primary) event. For any conclusion to be reached on this issue what is needed is an holistic study of inflation over the whole sporophore and an assessment of the correlation between cell behaviour in widely separated locations against an accurate time frame. This was done by Hammad et al. (1993b) for the mushroom of Coprinopsis cinerea, in which, unlike other agarics, the meiotic division is highly synchronised across the whole population of basidia.

This study established the exact timing of major events in meiosis and sporulation, using this as the basic timeline to which other processes could be referenced simply by microscopic examination of a small piece of cap tissue. This timeline is objective in the sense that it depends upon processes which are endogenously controlled. In the cultivation conditions described by Hammad et al. (1993b), sporophore primordia were formed $5 \mathrm{~d}$ after inoculation of the culture medium and developed into mature sporophores within 2-3 days, during which the basidia underwent a sequence of morphologically and physiologically distinctive stages. Defining karyogamy as time zero, basidia took $5 \mathrm{~h}$ to reach meiosis I and meiosis II was completed after a further hour. From meiosis II to the emergence of sterigmata required $1.5 \mathrm{~h}$, spores emerging $1.5 \mathrm{~h}$ after that. Spore formation continued for $1 \mathrm{~h}$ and then nuclear migration started. Spore pigmentation commenced $1 \mathrm{~h}$ after spore formation and spores matured and were discharged $7 \mathrm{~h}$ later.

Co-ordination of cell inflation was studied by measuring cell sizes in microscope sections of sporophores of Coprinopsis cinerea whose chronological development was defined by the stage they had reached in meiosis and sporulation. There was only a small increase in cell inflation before meiosis but much greater increases in sporophores undergoing meiosis. The most remarkable feature of these data was that rapid stem elongation was correlated with the ending of meiosis. Indeed, inflation of all the different cell types in the cap as well as elongation of cells of the stem began immediately after meiosis.

Elongation of the stem is necessary to raise the cap into the air for more effective spore dispersal; inflation of the different cell types in the gill tissue is also necessary for effective spore dispersal so co- 
ordination of cell inflation across the whole mushroom is clearly advantageous. The co-ordination that is observed may be achieved by some sort of signalling system that 'reports' the end of meiosis to spatially distant parts of the mushroom and initiates cell expansion. Indeed, stem elongation was significantly greater when the cap was left attached than when it was removed and leaving half of the cap in place was sufficient to ensure normal elongation; an effect observed with several species of mushroom over the years. Generally speaking, the elongating stem curves away from the side with the cap segment left intact (providing it contains gill tissues) and this has been interpreted as indicating that the gills are the source of a 'growth hormone'. Recently, research has been reported suggesting that chemically-modified sugars, formed in the gill tissues and secreted into the mucilage that surrounds the hyphae making up the Coprinopsis mushroom are most likely the signal that coordinates hyphal cell inflation across the whole mushroom (Moore \& Novak Frazer, 2017). The family of molecules are laevorotatory 6-deoxy hexoses that serve different signalling purposes by being substituted with amino and/or amido groups, and possibly $\mathrm{N}$-acetylated, phosphorylated or sulfated. They are thought to alter the substrate affinities of the normal hexose transporter. This could provide a general metabolic control mechanism with different chemically-modified hexoses being transported into the cell in response to different cytoskeletal signals and modulating the activity of existing proteins, some of which could be transcription activators. Chang et al. (2018a) identified a sugar transporter of Coprinopsis cinerea as a regulator of at least 12 associated genes.

\section{METABOLIC REGULATION IN RELATION TO MORPHOGENESIS}

We have emphasised the importance of cell inflation and tissue expansion in mushroom development, but there are several resources that must be provided to support these processes. Obviously, these demands include extensive synthesis of new cell wall and adjustment of metabolism so that osmotically active solutes are accumulated to drive water into the cells and cytoplasmic compartments that must be inflated. An extensive catalogue of changes in enzyme activities has been noted during the development of ink cap mushrooms of several different species. In Coprinopsis cinerea and Coprinus comatus development-related increases in the activities of glucosidase and glucanases, protease and chitinase have been noted during cap expansion (Iten, 1970; Iten \& Matile, 1970; Bush, 1974); so, degradation of the substance of the spent gill tissue is provided for by specific enzyme derepression. Whilst in the stipe, specific chitinases and glucanases act synergistically in cell wall extension of $C$. cinerea (Kang et al., 2019a; Zhou et al., 2019). In earlier stages, prior to the onset of autodigestion, a number of enzymes are specifically derepressed as tissues of the $C$. cinerea mushroom cap begin to form (Moore, 2013b). Four enzymes, NADP-linked glutamate dehydrogenase, glutamine synthetase, ornithine acetyltransferase and ornithine carbamoyltransferase, were highly depressed in developing caps while remaining low (or declining) in activity in the stems supporting those caps. Increases in these enzyme activities were initiated as karyogamy became evident in normally developing sporophores. Arginine synthesis and urea formation via the ornithine cycle occurred in the Coprinopsis cinerea mushroom cap and stem, but whilst urease occurred at high activity in mycelium and stem, it was not detectable in extracts of cap tissue (Moore \& Ewaze, 1976; Ewaze et al., 1978). Arginine, alanine and glutamate accumulated in the cap as a result of amplified arginine biosynthesis, but more significantly, urea content increased by a factor of 2.5 on a dry weight basis but the urea concentration on a fresh weight basis was essentially unchanged during cap development, which suggests a causal relationship between urea accumulation and water influx into developing tissues. Agaricus bisporus also accumulates substantial amounts of urea in sporophores, and content varied with stage of development (Wagemaker et al., 2005). However, in A. bisporus and Lentinula edodes, mannitol (a sugar alcohol, or polyol) is synthesised to serve an analogous osmoregulatory function to urea in Coprinopsis (Hammond \& Nichols, 1976; Tan \& Moore, 1994).

The conclusion is that urea is the osmotically-active metabolite in Coprinopsis cinerea and metabolism is adapted to enhance the flow of nitrogen towards the urea cycle; all of this being devoted to driving water into the cap tissue to enable its expansion. But that's not the whole of the sporophore metabolism story. In this system, coregulation of NADP-glutamate dehydrogenase and glutamine synthetase produces a classic ammonium scavenging system, usually produced to alleviate 
nitrogen deprivation and contribute to amino acids needed for protein synthesis. This does not fit with the observed accumulation of arginine, alanine and glutamate in the $C$. cinerea cap where aminonitrogen must be obtainable readily from autodigested proteins, so it is unlikely that the ammonium-scavenging GDH and GS activities are needed to assimilate nitrogen at this late stage in mushroom maturation.

However, a consequence of enzymatic scavenging is that the scavenged substrate is very effectively removed from the cytoplasm, so an alternative interpretation is that these two enzymes are derepressed to maintain an ammonium-free environment in cells committed to processes which are inhibited by ammonium. Now, NADP-GDH activity has been specifically localised to basidia in $C$. cinerea cap tissue; consequently, the cells we are talking about are basidia, which are specialised for meiosis. And, indeed, it seems that proper progress of meiosis in eukaryotes generally may depend on ammonium-sensitive processes. Glycogen breakdown, DNA synthesis, and extensive RNA and protein breakdown occur together uniquely in fungal meiocytes; and all these processes seem to be inhibited by ammonium ions (Moore et al., 1987a and references therein; Fig. 7). This is true even in yeast:

The interpretation is, therefore, that NADP-GDH and GS activities are specifically enhanced in basidia of Coprinopsis cinerea to protect those cells from the inhibitory effects of ammonium ions, and meiosis and sporulation were indeed shown to be sensitive to inhibition by ammonium ions by direct experiments in vitro and in vivo (Fig. 7) (Bastouill-Descollonges \& Manachère, 1984; Chiu \& Moore, 1988a, 1988b, 1990c).

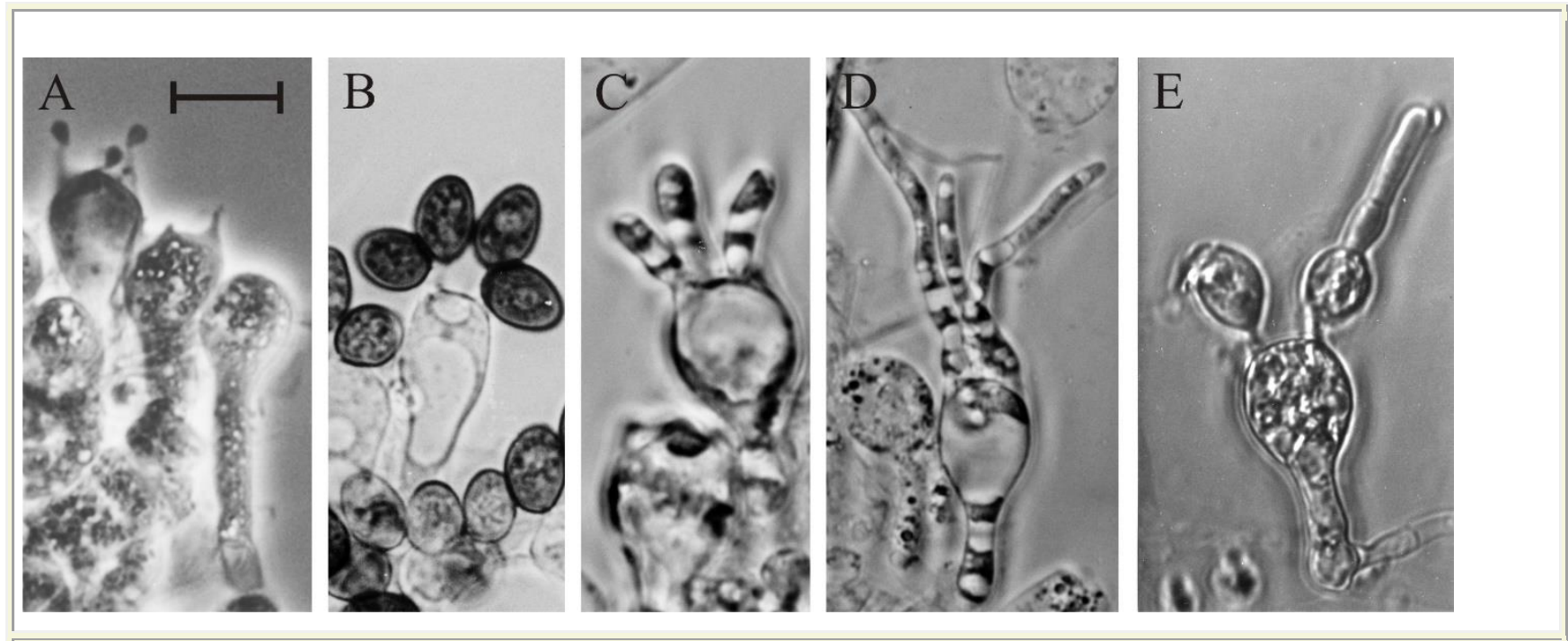

Fig. 7. Basidium development of Coprinopsis cinerea is disrupted by application of ammonium salts. This can be demonstrated by in vitro experiments in which slivers of gill tissue cut from a developing mushroom are transferred to agar medium. Providing they are transplanted after prophase I of meiosis (A), Coprinopsis basidia are committed to continue development and they complete meiosis and spore formation after excision from the mushroom and transfer to water agar (B). If ammonium salts are included in the medium normal developmental is arrested; instead of forming sterigmata and spores, ammonium-treated basidia immediately dedifferentiate to produce vegetative hyphal tips $(C, D$ and $E$ ) from regions of active wall growth. In $C$ and $D$, the sterigmata have grown out as vegetative hyphal tips. In $E$ the hyphal tip has grown from the top of an incomplete spore. Note that this is not equivalent to premature germination because the germ pore (from which a mature spore will germinate) is located close to the sterigma attachment point. In specimen $E$ the ammonium treatment has caused the emergence of a hyphal tip from a region of primary wall growth in the incomplete spore. Scale bar $=10 \mu \mathrm{m}$. Photomicrographs by Prof. S.-W. Chiu, Chinese University of Hong Kong. Illustration modified from Moore (1998a).

The inference from these experiments is that within the normally-developing Coprinopsis cinerea mushroom, ammonium-scavenging enzymes are specifically derepressed to prevent ammonium ions 
halting meiocyte differentiation and terminating sporulation. The ecological significance seems to be that as $C$. cinerea grows naturally in compost where ammonia is abundant and volatile, so the ammonium assimilating enzymes are produced in the cap to serve as an efficient ammoniumscavenging system that maintains the microenvironment surrounding the hymenium free from the inhibitor.

\section{GENETIC APPROACHES TO STUDY DEVELOPMENT: THROUGH THE CLASSIC TO GENOMIC SYSTEMS ANALYSIS}

The classic genetic approach to the study of any pathway depends on:

- identification of variant strains;

- complementation tests to establish functional cistrons;

- comparison of heterokaryon phenotypes to determine dominance;

- determination of epistatic relationships in heterokaryons, to indicate the sequence of gene expression (Moore \& Novak Frazer, 2002).

This, of course, now looks like a rather old-fashioned approach, though it's lost none of its power to dissect an individual pathway. The modern molecular approach is to use genomic analysis tools to analyse and compare the transcriptome (transcribed RNA population) and/or proteome (translated polypeptide population) to give expression profiles of different stages as the organism progresses through its developmental sequence. The classic approach ('first, find a variant') immediately focuses attention on a decisive event, though it can then be difficult to identify the network of interactions to which this belongs (the network only begins to become evident as more and more individual decisive events are dissected out, which can take a long time and a lot of work).

In contrast, genome-wide analysis gives you an immediate view of the overall grand network, which comprises many thousands of interactions, and it can then be difficult to bring the focus down to identify the few decisive events that enable neighbouring cells in a hypha to embark on different developmental pathways. The abstract of one paper, which describes gene expression studies during mushroom development in Coprinopsis cinerea concludes with the sentence:

'...We implicated a wealth of new candidate genes important to early stages of mushroom ... development, though their precise molecular functions and biological roles are not yet fully known... (Cheng et al., 2013).'

Finding out what all those genes do can take a long time and a lot of work. We will describe some of this work in this Section, as it applies to the organisms we have already mentioned, but it is easier for us to continue our story about Coprinopsis cinerea with a trip down Memory Lane to the pre-genomics era. The classic genetic approach, when applied to Coprinopsis cinerea, resulted in the isolation of, among others: stipe elongationless mutants, which were unable to elongate the stem but with normal cap expansion, or cap expansionless mutants unable to expand the cap but with normal stipe elongation, and sporeless mutants in which the sporophores were morphologically completely normal except for the total absence of spores (Takemaru \& Kamada, 1971, 1972) (Fig. 8).

The three mutants were all dominant and segregated in crosses as single genes. Evidently, the pathways of cap and stem differentiation can be totally separated, and the sporulation pathway is separate from normal cap development. This leads to the conclusion that assembly of different parts of the same sporophore uses genetically distinct pathways. That conclusion can be generalised to:

- differentiation of fungal multicellular structures is genetically compartmentalised and normal morphogenesis is made up of several-to-many developmental subroutines. 


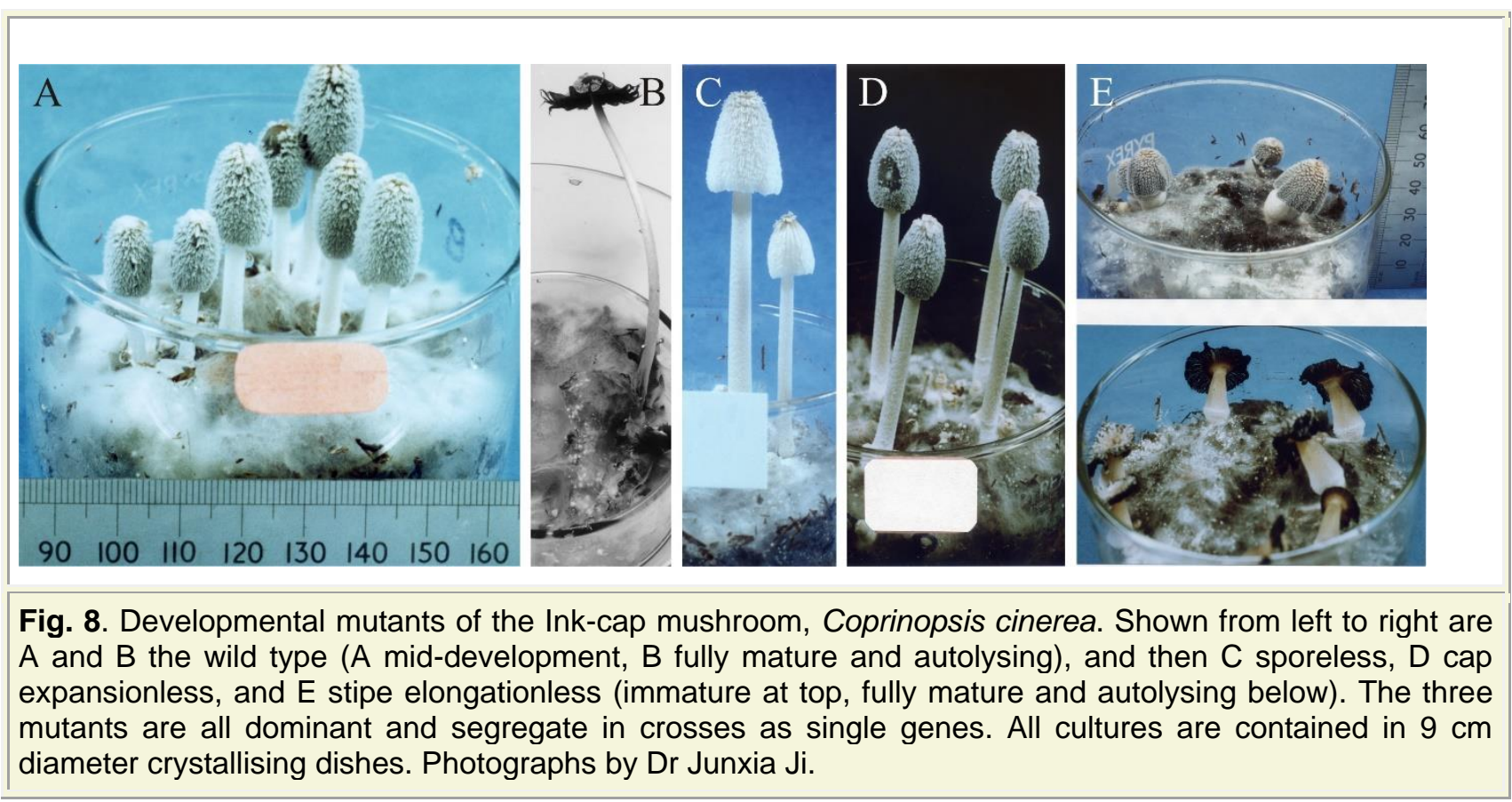

For example, there may be subroutines for stem, cap, hymenium, hymenophore, etc. The subroutines can be put into operation independently of one another and are under separate genetic control and under separate physiological control. Normal morphogenesis of a specific fungus involves integration of these subroutines to produce the sporophore morphology that characterises that species. In their analysis of complex multicellularity in fungi, Nagy et al. (2018) use a slightly different description, suggesting that gene regulatory circuits that orchestrate sporophore development in fungi evolved in a stepwise manner, building on ancient regulatory modules, but also on co-option of conserved genes coupled with the evolution of new ones.

Another important point is that fungi are very tolerant of developmental imprecision. Providing only that the sporulation pathway is intact, even a grossly abnormal sporophore can produce and distribute spores. Variation in the morphology of sporophores of higher fungi has been reported in many species, often as a strategy for adaptation to environmental stress. Detailed analysis of such developmental plasticity in spontaneous abnormal sporophores of Volvariella bombycina (Chiu et al., 1989), ranging from the normal agaric form to completely abnormal puff-ball like structures, showed they were all able to act as production/dispersal structures for basidiospores. More evidence for normal morphogenesis being an assemblage of distinct developmental segments. This tolerance of imprecision is an important biological attribute of fungal morphogenesis, as it provides the flexibility in expression of developmental subroutines that allows the sporophore to react to adverse conditions and still produce a crop of spores (Moore, 1998b; 2013b).

Coprinopsis cinerea was included in the list of fungi chosen for the Fungal Genome Initiative in 2002 (Cuomo \& Birren, 2010), and the genome of Coprinopsis cinerea, which comprises 36 megabase pairs was sequenced and assembled into 13 chromosomes by an international team of 47 researchers (Stajich et al., 2010). This was used to investigate how rates of meiotic recombination varied along the chromosomes, and the distribution, expression, and conservation of single-copy genes and gene families.

The genome project revealed two genes of the DNA (cytosine-5)-methyltransferase-1 family that catalyses transfer of methyl groups to specific CpG structures in DNA to form 5-methylcytosine, a process called DNA methylation. This confirmed prior studies which showed methylation of repeated genes in Coprinopsis cinerea. DNA methylation is used to control gene expression by changing the 
activity of DNA without changing the sequence; methylation of a gene's promoter typically represses transcription. The Coprinopsis cinerea genome contained 38 copies of a gene predicted to catalyse the formation of the additional modified base, 5-hydroxymethylcytosine, which has been detected in $C$. cinerea DNA.

This is especially relevant to our current discussion of fungal development because 5hydroxymethylcytosine has a role in the 'poised (or bivalent) chromatin' domains found in embryonic stem cells that play an important role in mammalian cell differentiation. Poised (bivalent) chromatin is defined by the simultaneous presence of histone modifications associated with both gene activation and gene repression and is usually found near promoters of transcriptionally silent developmental regulatory genes. In general, pluripotent cells (capable of giving rise to several different cell types) have high numbers of poised domains compared with more differentiated cells, and these domains tend to resolve toward a purely active or purely repressed state during differentiation (Voigt et al., 2013; Lesch \& Page, 2014).

5-Methylcytosine in DNA of eukaryotes is an important mark for epigenetic gene regulation; silencing certain gene sequences and activating others so that cells can differentiate. The 'ten eleven translocation' enzymes (TET; the enzymes are named for a common translocation in human cancers) oxidise 5-methylcytosines and promote locus-specific reversal of DNA methylation. ' $J$ binding proteins' (JBP; originally named for their effect on glycosylated thymine in trypanosome DNA, which is known as base $\mathrm{J}$ ) catalyse hydroxylation of bases in nucleic acids. TET/JBP enzymes are a family of nucleic acid base-modifying 2-oxoglutarate and iron-dependent dioxygenases that demethylate by converting 5-methylcytosine to oxidised methylcytosines, such as hydroxy-, formyl-, and carboxymethylcytosine, which serve as further epigenetic marks or intermediates for demethylation.

lyer et al. (2014) showed that fungi, especially all major clades of basidiomycetes (and including Coprinopsis and Laccaria), have numerous TET/JBP genes, which are often associated with a unique class of transposable elements. This pattern differs starkly from the situation in most other organisms that possess just a single or a few copies of the TET/JBP family. Strikingly, unlike typical transposonassociated genes, where only a few of the many copies are active in a genome, analysis of the TET/JBP domains in mushrooms showed that the majority of them are predicted to be catalytically active. This unique transposon-TET/JBP association in fungi is likely to play important roles in speciation during evolution and in epigenetic regulation. 5-methylcytosine $(5 \mathrm{mC})$ and oxidised methylcytosines (oxi-mCs) have been mapped in Coprinopsis cinerea at close to base-pair resolution (Chavez et al., 2014), and this revealed that distinctive patterns of $5 \mathrm{mC}$ and oxi-mC occurred in centromeres and transposable elements, and within silenced duplicated genes..

The Coprinopsis cinerea genome includes several highly-expanded unusual protein kinase families including some orthologous to kinases of Saccharomyces cerevisiae, several kinase classes found in animals and/or Dictyostelium, but lost from yeast, and a hugely expanded (to 133 members) family of FunK1 kinases. Protein kinases are enzymes that regulate the activity of other enzymes by phosphorylation, which may turn an inactive enzyme into an active form (or vice versa), or otherwise change an enzyme's activity, cellular location, or its interaction with other proteins.

FunK1 kinases are only found in multicellular ascomycete and basidiomycete fungi. The unusually large gene family in Coprinopsis cinerea shows considerable coding diversity; and 59 of the 133 FunK1 family genes are found within a short region near the end of chromosome 9, overlapping a recombination hot spot in a region where meiotic synapsis initiates. The FunK1 kinases are differentially expressed during dikaryon formation, so they appear to have important roles in sexual morphogenesis and development of Coprinopsis cinerea.

Finally, when the genomes of Coprinopsis cinerea and Laccaria bicolor, an ectomycorrhizal basidiomycete that grows in mixed birch and pine woods, were compared they were found to share extensive regions of synteny (meaning blocks of genes in a similar order within two sets of 
chromosomes that are being compared with each other). The largest syntenic blocks were found to occur in regions with low meiotic recombination rates, no transposable elements, and tight gene spacing (Stajich et al., 2010).

More evidence of tissue and development-specific gene control was found by studies that focussed on the transcriptional programme of Coprinopsis cinerea. Burns et al. (2010) examined the transcripts produced during meiosis, including time points extending over the 15 hours from before haploid nuclear fusion through to formation of basidiospore tetrads. They found that about $20 \%$ of the genes in the genome are differentially regulated during this developmental process, with successive waves of transcription apparent in nine transcriptional clusters, one of which was enriched for meiotic functions.

Transcriptional waves of this sort in other organisms have been found to represent differential expression of genes essential for recombination, chromosome cohesion, chromosome segregation, etc. Comparison with meiotic expression data from Saccharomyces cerevisiae and Schizosaccharomyces pombe showed that meiotic regulatory machinery was not conserved. Not too surprising, perhaps as, physiologically, both yeasts are stimulated to enter meiosis by nutritional limitation, while induction of sporophore development and meiosis in Coprinopsis cinerea is largely controlled by illumination and temperature.

However, a 'core meiotic transcriptome' of 75 genes was conserved between the three fungi. Ascomycetes and basidiomycetes are thought to have diverged in evolution about 500 to 900 million years ago, with Saccharomyces cerevisiae and Schizosaccharomyces pombe diverging from one another shortly after. Conservation of the core meiotic transcriptome between these three fungi implies that the essential transcriptional programme of meiosis has persisted through at least half a billion years of evolution, and potentially for up to a billion years (Burns et al., 2010).

The transcription pattern during the transition from the vegetative mycelium to the primordium during sporophore development of Coprinopsis cinerea was first examined by Cheng et al. (2013). They evaluated the expression of more than 3,000 genes in both growth stages and discovered that almost one-third of these genes were preferentially expressed in one or other stage. The data indicated that various structural and functional protein families were uniquely employed in one or other stage and that during primordial growth, cellular metabolism is highly up-regulated. Various signalling pathways were also up-regulated, particularly:

- the 'protein kinase A' family of enzymes whose activity is dependent on cellular levels of cyclic AMP (cAMP-PKA),

- the 'mitogen-activated protein kinase' family (MAPK)

- the 'target of rapamycin' (TOR) signaling pathway, which integrates both intracellular and extracellular signals and serves as a central regulator of cell metabolism.

All of which is consistent with the idea that sensing of nutrient levels and environmental conditions are important in this developmental transition. Interestingly, over 100 of the up-regulated genes were found to be unique to mushroom forming basidiomycetes, highlighting the novelty of sporophore development in these fungi (Cheng et al., 2013).

The transcriptomes of stage 1 primordia and vegetative mycelium of Coprinopsis cinerea were also studied by Plaza et al. (2014), but these authors paid attention to regulation of the expression of defence genes as well as the conserved transcriptional patterns of sexual reproduction. Comparing their results with analogous data from Laccaria bicolor and Schizophyllum commune revealed a conserved transcriptional circuitry in basidiomycete sporophores consisting of nearly 70 genes involved in mushroom development and function. 
They also found evidence for a role of the 'Velvet protein regulon' in sexual development of basidiomycetes, as a velvet domain-containing protein was found to be up-regulated in all three fungi. The four velvet proteins $\mathrm{VeA}$, VelB, VelC, and VosA share a region of about 150 amino acids, the velvet domain, which lacks sequence homology to any other proteins. They were originally identified in Aspergillus nidulans and shown to form a family of fungal regulators that couple together lightregulated processes, control of secondary metabolism, growth, and differentiation (Bayram et al., 2008; Ahmed et al., 2014).

These velvet regulators are present in most clades of the fungal kingdom from chytrids to basidiomycetes. Velvet proteins have presumably been recruited into the basidiome transcriptional circuit as they are one of the most ancient systems regulating the production of asexual spores in fungi (Etxebeste et al., 2019). In contrast to the central regulator BrlA, which regulates Aspergillus conidiophores and emerged later in fungal evolution, with the class Eurotiomycetes.

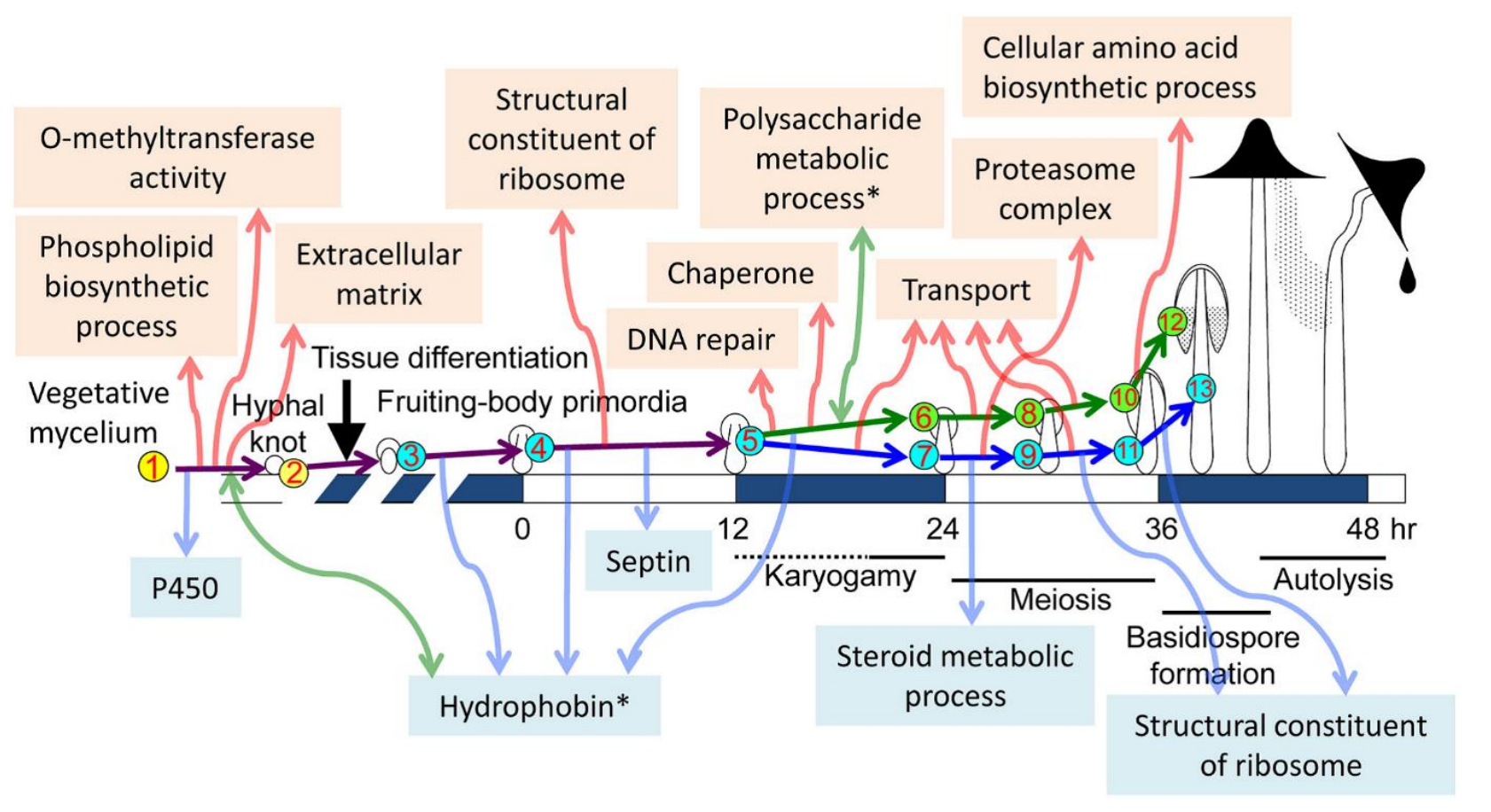

Fig. 9. Summary of major transcriptional events during morphogenetic transitions during mushroom development in Coprinopsis cinerea. The cartoon diagrams of sporophores across the centre run from vegetative mycelium at left to autolysing mature mushroom at right and are placed on an average time scale with time zero being set by the illumination cycle that triggers primordium maturation. The nine developmental stages selected to investigate the transcriptome are shown with numbers in circles (cap and stipe tissue samples were taken separately from $24 \mathrm{~h}$ onwards). Developmental and cellular events in each stage and tissue are shown in Table 1. The study identified differentially expressed gene sets using GO enrichment analysis; that is, sets of gene sequences of related function that are up-regulated or down-regulated in pairwise comparisons between two succeeding developmental stages, and between vegetative mycelium and each individual developmental stage [http://geneontology.org/page/go-enrichment-analysis]. The program does this by statistically determining which sequence(s) are over-represented (or under-represented) in each member of the pair relative to the other. Notable transcriptional programme events are depicted in the text labels. Events detected by up-regulated differentially expressed genes are indicated in the upper part with upward red arrows; down-regulated differentially expressed gene sets are shown in the lower part with downward blue arrows. Sets which featured a mix of both up-regulated and downregulated gene sequences of related function are indicated with asterisks and bidirectional green arrows. Reproduced from Muraguchi et al. (2015) under Creative Commons licence https://creativecommons.org/licenses/by/4.0/. 
Muraguchi et al. (2015) extended the investigation of the transcriptome during mushroom development in Coprinopsis cinerea by using high-throughput sequencing of cDNA libraries from 13 developmental points (nine developmental stages, but from stage 6 (onset of meiosis) cap and stipe tissues were analysed separately; see Table 1).

The analysis revealed changes in expression of many differentially expressed genes between two succeeding developmental stages and between vegetative mycelium and each developmental stage. GO analysis of differentially expressed genes (DEGs) in each transition revealed an overall developmental framework and many notable cellular events; these results are summarised in Fig. 9 and Table 1.

Conclusions reached in the pregenomics era have been broadly confirmed by genome systems analysis, though expanded and given their quantitative context (Table 1).

Table 1. Major morphogenetic events and transcriptional transitions during mushroom development in Coprinopsis cinerea

\begin{tabular}{|c|c|c|c|c|c|}
\hline \multirow{2}{*}{$\begin{array}{l}\text { Tissue } \\
\text { designation }\end{array}$} & \multirow{2}{*}{ Cellular events } & \multicolumn{4}{|c|}{ Differential expression in each transition between developmental stages } \\
\hline & & Transition & Regulation & Transcripts & Top 3 functions \\
\hline \multirow{2}{*}{$\begin{array}{l}\text { 1. vegetative } \\
\text { mycelium }\end{array}$} & \multirow{2}{*}{$\begin{array}{l}\text { Apical growth, } \\
\text { branching, } \\
\text { ageing }\end{array}$} & \multirow{2}{*}{$1-2$} & UP & 408 & $\begin{array}{l}\text { Phospholipid biosynthesis; O- } \\
\text { methyltransferase activity; } \\
\text { extracellular region } 1\end{array}$ \\
\hline & & & DOWN & 134 & $\begin{array}{l}\text { Cytochrome P450; } \\
\text { hydrophobin } 1 ; \text { adenyl } \\
\text { nucleotide binding }\end{array}$ \\
\hline \multirow{2}{*}{$\begin{array}{l}\text { 2. mycelium \& } \\
\text { hyphal knots }\end{array}$} & \multirow{2}{*}{$\begin{array}{l}\text { Central and } \\
\text { surface cells } \\
\text { differentiate }\end{array}$} & \multirow{2}{*}{$2-3$} & UP & 2 & - \\
\hline & & & DOWN & 3 & - \\
\hline \multirow{2}{*}{$\begin{array}{l}\text { 3. small } \\
\text { primordia }\end{array}$} & \multirow{2}{*}{$\begin{array}{l}\text { Stipe and cap } \\
\text { clearly } \\
\text { demarcated }\end{array}$} & \multirow[b]{2}{*}{$3-4$} & UP & 85 & adenyl nucleotide binding $₫$ \\
\hline & & & DOWN & 38 & $\begin{array}{l}\text { adenyl nucleotide binding } 1 \text {; } \\
\text { hydrophobin }\end{array}$ \\
\hline \multirow{2}{*}{$\begin{array}{l}\text { 4. primordia } \\
\text { begin } \\
\text { maturation 0-h }\end{array}$} & \multirow{2}{*}{$\begin{array}{l}\text { Light stimulation; } \\
\text { set as time zero }\end{array}$} & \multirow{2}{*}{$4-5$} & UP & 148 & $\begin{array}{l}\text { Structural constituent of } \\
\text { ribosome; zinc ion binding; } \\
\text { FAD binding }\end{array}$ \\
\hline & & & DOWN & 590 & $\begin{array}{l}\text { Hydrophobin; fungal } \\
\text { phospholipid biosynthesis; } \\
\text { septin complex }\end{array}$ \\
\hline \multirow{4}{*}{$\begin{array}{l}\text { 5. whole } \\
\text { primordium at } \\
12-h\end{array}$} & \multirow{4}{*}{$\begin{array}{l}\text { Pre-meiotic DNA } \\
\text { replication starts }\end{array}$} & \multirow{2}{*}{$5-6$} & UP & 949 & $\begin{array}{l}\text { DNA repair; chaperonin } \\
\text { Cpn60/TCP-1; glucose } \\
\text { catabolism } \uparrow\end{array}$ \\
\hline & & & DOWN & 1,660 & $\begin{array}{l}\text { Hydrophobin; cytochrome } \\
\text { P450; polysaccharide } \\
\text { metabolism }\end{array}$ \\
\hline & & \multirow[b]{2}{*}{$5-7$} & UP & $3,301^{*}$ & $\begin{array}{l}\text { Transport; FAD binding; ATP } \\
\text { coupled proton transport }\end{array}$ \\
\hline & & & DOWN & $3,569^{*}$ & $\begin{array}{l}\text { Structural constituent of } \\
\text { ribosome; RNA processing; } \\
\text { RNA recognition motif, RNP-1 }\end{array}$ \\
\hline \multirow{2}{*}{$\begin{array}{l}\text { 6. cap, 24-h } \\
\text { after light } \\
\text { trigger }\end{array}$} & \multirow{2}{*}{$\begin{array}{l}\text { Karyogamy in } \\
\text { basidia }\end{array}$} & \multirow[b]{2}{*}{$6-8$} & UP & 2,471 & $\begin{array}{l}\text { Transport; FAD binding; } \\
\text { cytochrome P450 }\end{array}$ \\
\hline & & & DOWN & 2,034 & $\begin{array}{l}\text { RNA recognition motif, RNP-1; } \\
\text { RNA processing; structural } \\
\text { constituent of ribosome }\end{array}$ \\
\hline
\end{tabular}




\begin{tabular}{|c|c|c|c|c|c|}
\hline \multirow{2}{*}{$\begin{array}{l}\text { 7. stipe, } 24-h \\
\text { after light } \\
\text { trigger }\end{array}$} & \multirow{2}{*}{$\begin{array}{l}\text { Stipe nuclei } \\
\text { divide before } \\
\text { elongation }\end{array}$} & \multirow[t]{2}{*}{$7-9$} & UP & 457 & $\begin{array}{l}\text { Proteasome complex; AMP- } \\
\text { dependent synthetase and } \\
\text { ligase; EF-hand calcium- } \\
\text { binding proteins }\end{array}$ \\
\hline & & & DOWN & 326 & $\begin{array}{l}\text { Steroid metabolism; lipase } \\
\text { activity; lipid biosynthesis }\end{array}$ \\
\hline \multirow[b]{2}{*}{$\begin{array}{l}\text { 8. cap, } 30-h \\
\text { after light } \\
\text { trigger }\end{array}$} & \multirow[b]{2}{*}{ Karyogamy + 6-h } & \multirow[b]{2}{*}{ 8-10 } & UP & $3,465^{\star}$ & $\begin{array}{l}\text { Transmembrane; FAD binding; } \\
\text { cytochrome P450 }\end{array}$ \\
\hline & & & DOWN & $3,197^{*}$ & $\begin{array}{l}\text { Structural constituent of } \\
\text { ribosome; WD40 repeat } \\
\text { histone binding proteins; } \\
\text { vesicle-mediated transport }\end{array}$ \\
\hline \multirow[b]{2}{*}{$\begin{array}{l}\text { 9. stipe, } 30-h \\
\text { after light } \\
\text { trigger }\end{array}$} & \multirow[b]{2}{*}{ Stipe enlarges } & \multirow[b]{2}{*}{$9-10$} & UP & 2,088 & $\begin{array}{l}\text { Transport; vitamin B6 binding; } \\
\text { cytochrome P450 }\end{array}$ \\
\hline & & & DOWN & 2,356 & $\begin{array}{l}\text { Structural constituent of } \\
\text { ribosome; WD40 repeat } \\
\text { histone binding proteins; } \\
\text { ribosome biogenesis }\end{array}$ \\
\hline $\begin{array}{l}\text { 10. cap, 36-h } \\
\text { after light } \\
\text { trigger }\end{array}$ & $\begin{array}{l}\text { Karyogamy + 12- } \\
h\end{array}$ & \multirow[t]{2}{*}{$10-12$} & UP & 1,743 & $\begin{array}{l}\text { Nitrogen compound } \\
\text { biosynthesis; cellular amino } \\
\text { acid biosynthesis; alcohol } \\
\text { dehydrogenase GroES-like fold } \\
\text { proteins (catalytic domain of } \\
\text { alcohol dehydrogenases) }\end{array}$ \\
\hline $\begin{array}{l}\text { 12. cap, 39-h } \\
\text { after light } \\
\text { trigger }\end{array}$ & $\begin{array}{l}\text { Karyogamy + 15- } \\
\text { h spores form }\end{array}$ & & DOWN & 1,701 & $\begin{array}{l}\text { ATP binding; N-terminal FAD } \\
\text { linked oxidase; galactose } \\
\text { oxidase, beta propeller (ligand- } \\
\text { binding) }\end{array}$ \\
\hline $\begin{array}{l}\text { 11. stipe, } 36-h \\
\text { after light } \\
\text { trigger }\end{array}$ & $\begin{array}{l}\text { Stipe starts to } \\
\text { elongate }\end{array}$ & \multirow{2}{*}{$11-13$} & UP & 136 & $\begin{array}{l}\text { Cytochrome P4501; C2H2- } \\
\text { type zinc finger proteins } \\
\text { (transcription factors); metal } \\
\text { ion-binding }\end{array}$ \\
\hline $\begin{array}{l}\text { 13. stipe, 39-h } \\
\text { after light } \\
\text { trigger }\end{array}$ & $\begin{array}{l}\text { Stipe elongates } \\
\text { Cap expands }\end{array}$ & & DOWN & 192 & $\begin{array}{l}\text { Cytochrome P450£; FAD } \\
\text { binding; structural constituent } \\
\text { of ribosome }\end{array}$ \\
\hline \multicolumn{6}{|c|}{$\begin{array}{l}\text { I, sets which featured a mix of both up-regulated and downregulated differentially expressed gene sequences of } \\
\text { related function are indicated with this bidirectional arrow and green text. } \\
\text { *, indicates that only the first } 3,000 \text { genes were analysed. } \\
\text { Data from Muraguchi et al. }(2015) \text { [https://doi.org/10.1371/journal.pone.0141586]. }\end{array}$} \\
\hline
\end{tabular}

Several hundred to a thousand genes are preferentially expressed at different stages in development of the sporophore. Various signalling pathways have been implicated including CAMP-PKA, MAPK and TOR, the fungus-specific velvet protein regulon and the FunK1 kinases, which are only found in multicellular ascomycete and basidiomycete fungi.

Considering the reference in Fig. 1 to cycles of glycogen accumulation and translocation in different sporophore tissues it is interesting to see in Fig. 9 that the category 'polysaccharide metabolic process' is a set that featured a mix of both up-regulated and down-regulated transcripts. Indeed, transcriptional profiling is beginning to unravel this 'glycogen regulatory circuit' by showing that glycogen synthase kinase 3 (GSK-3) activity is essential for mushroom formation in Coprinopsis cinerea by directly affecting expression of sporophore induction genes together with genes in downstream cellular processes (Chan et al., 2018); and experimental inhibition of GSK-3 expression can control sporophore development (Chang et al., 2018b). 
Similarly, the importance attached to enzymes involved in ammonium scavenging and the urea cycle (see Section 10 above) fits well with the up-regulation of transcripts in the category 'cellular amino acid biosynthetic process'. There are several other features of Fig. 9 that confirm deductions from the pregenomics era, particularly the up-regulation of 'transport' transcripts in both cap and stipe between stages 5 and 6/7, and then again between $6 / 7$ and 8/9, and yet again between 8/9 and 10/11; all of which confirm the presumed rapid translocation of metabolites and water during mushroom maturation.

Perhaps not quite so obvious is that the up-regulation of transcripts in the 'extracellular matrix' category fits well with what was known about the importance of the extracellular matrix to hyphal knot formation; and the up-regulation of 'proteasome complex' in the stipe between stages $6 / 7$ and 8/9, with the implication that protein degradation is important to the stipe at these stages is compatible with what is known about the biochemistry of the Coprinopsis stipe which, unusually, does not accumulate sugars or polyols and is likely, therefore to use the carbon skeletons of amino acids derived from protein degradation as energy sources.

Furthermore, the conclusion that differentiation of fungal multicellular structures is genetically compartmentalised with normal morphogenesis being made up of several-to-many developmental subroutines (see above in this Section) are equivalent to the transcriptional clusters, transcriptional waves of differential gene expression and differentially expressed gene sets detected in studies of the transcriptional programme of the Coprinopsis cinerea genome.

Differential transcriptional patterns of a family of glycoside hydrolases of Coprinopsis cinerea matched well with the requirement for the wall-softening that these enzymes effect in the germination of basidiospores, hyphal growth and branching, primordium formation, stipe elongation, pileus expansion and autolysis (Kang et al., 2019b). Some members of the family were predominantly expressed in dormant basidiospores, primordia and during basidiosporogenesis. Other members were dominantly expressed in the germinating basidiospores, growing mycelia, and elongating stipes. The dynamics of the proteome during sporophore development in $C$. cinerea has also been studied (Majcherczyk et al., 2019).

Muraguchi et al. (2015) observed dramatic changes in gene expression of some transcription factor networks, and several examples of natural antisense transcripts (NATs) that are likely to be involved in developmental regulation of sporulation. NATs are widespread in eukaryotes; they are RNAs that are complementary to other ('sense') RNA transcripts. Evidence indicates that sense and antisense transcripts interact, suggesting a role for NATs in the regulation of gene expression (Wight \& Werner, 2013).

MicroRNAs (miRNAs) are about 22 nucleotides in length and have essential roles in posttranscriptional regulation of gene expression in animals and plants. Although little studied in fungi, microRNAs have been associated with early mushroom development in Coprinopsis cinerea, where Lau et al. (2018) established their potential targets and demonstrated differential miRNA expression during the early developmental stages of the mushroom, suggesting their involvement in regulating development in this fungus.

Krizsán et al. (2019) constructed a reference atlas of mushroom formation based on comparisons of developmental transcriptome data of more than 200 whole genomes belonging to six species of Agaricomycetes (Armillaria ostoyae, Coprinopsis cinerea, Lentinus tigrinus, Phanerochaete chrysosporium, Rickenella mellea and Schizophyllum commune). 12,003 to 17,822 expressed genes were detected in the six species of which 938 to 7,605 were developmentally regulated. Importantly, nearly 300 conserved gene families in more than 70 functional groups contained developmentally regulated genes. These data outline the major multicellularity-related and developmental processes of mushrooms, including the role of transcriptional reprogramming, gene coexpression networks (called 'modules' by the authors but corresponding to the developmental subroutines discussed above), 
and alternative splicing. Many of the developmentally regulated sequences were expanded in multicellular plants and/or animals too, implying convergent evolution towards solutions to the challenges imposed by complex multicellularity within independently evolving lineages. Data relating to the evolutionary age distribution of developmentally regulated genes suggested that most developmental gene families are older than sporophore formation; the sequences falling into three groups (a) genes shared by all living species, (b) genes shared by the Dikarya (Ascomycota and Basidiomycota), and (c) species-specific genes.

Another promising technique for detecting transcriptional regulatory relationships on a genome-wide scale that is beginning to be applied to fungal development is the analysis of expression Quantitative Trait Loci (eQTL). A quantitative trait locus (QTL) is a DNA segment associated with a particular phenotype, which varies across a population in a manner attributed to polygenic control (presumed to be the product of two or more genes together with their environment). The approach is essentially a metagenomic statistical analysis of variation in the phenotype of interest that can reveal the genetic architecture of that trait; that is, whether phenotype is controlled by many genes of small effect, or by a few genes of large effect. Expression quantitative trait loci (eQTLs) are genomic loci that describe the variation in expression levels of mRNA molecules. Analysis of eQTLs can recognise potential regulatory factors of gene expression and could identify master regulators in the genome (Michaelson et al., 2009; Liseron-Monfils \& Ware, 2015; Cheng et al., 2016; Chang et al., 2018a).

We already knew about the extensive use of transcription factors to direct transcription to specific genes in fungi, particularly the homeodomain proteins of the mating type factors (Bobola \& Merabet, 2017; Vonk \& Ohm, 2018), so we add those to the list of potential fungal regulators. We should also add to that list of regulators translational triggering and feedback fixation, discovered in the 1990s in research on Aspergillus nidulans conidiophores (detailed in Section 10.4 of Moore et al., 2020), which solve the problems of how to respond to a transient signal, and how to maintain that response when the signal has dissipated. The mechanism involves a genetic sequence, in this case the brlA locus, that codes for an RNA transcript containing overlapping reading frames.

Alternative splicing of precursor mRNA is now established as an essential mechanism to increase the complexity of gene expression that plays an important role in cellular differentiation and development in eukaryotes (Wang et al., 2015). Alternative splicing is common in higher plants and animals and increases the coding capacity from a limited set of genes. Grützmann et al. (2014) claim that alternative splicing is also a common phenomenon in fungi, and that, on average, about $6.0 \%$ of genes in ascomycetes, and $8.6 \%$ of basidiomycete genes show alternative splicing (Cryptococcus neoformans had the extraordinary rate of $18 \%$ ), and that this process is associated with multicellular complexity, dimorphic switching, stress response and pathogenic virulence.

Fungal mycelia, sporophore primordia and mature sporophores are attractive sources of food to small animals including molluscs, arthropods and nematodes (see Section 12.2 of Moore et al., 2020), and it is well known that mushrooms produce defence proteins and secondary metabolites to deter such predators and other competitors.

Plaza et al. (2014) revealed the existence of two different sets of fungal defence proteins in the proteomes of sporophore primordia of Coprinopsis cinerea. One of the primordium-specific proteins is toxic to insects and nematodes and the expression pattern of these proteins correlates with the type of antagonists with which these tissues are confronted. For instance, cytoplasmic lectins, also referred to as sporophore lectins due to their specific expression pattern, have been shown to be toxic to nematodes, insect larvae and amoebae (Bleuler-Martínez et al., 2011; see Section 15.6 of Moore et al., 2020).

In contrast, vegetative mycelia secrete antibacterial peptides which deter competing bacteria. Known as defensins, these are found in vertebrates, higher plants and invertebrates as well as saprotrophic fungi (Wu et al., 2014). Defensins have therapeutic promise; plectasin, isolated from the ascomycete 
Pseudoplectania nigrella, is especially active against Streptococcus pneumoniae, including strains resistant to conventional antibiotics. Genome editing techniques are now available to manipulate production of potentially useful metabolites like these (Doudna \& Sontheimer, 2014; and see Section 6.10 of Moore et al., 2020), and a novel method of high-throughput CRISPR/Cas9-based genome editing of Coprinopsis cinerea using cryopreserved protoplasts has been reported (Sugano et al., 2017).

Surprisingly, there is no mention in any of these studies of homologues of sequences signalling mechanisms which are essential and highly conserved components of normal development in animals. Comprehensive mining of fungal genomes for homologies to all developmental sequences in all sequenced genomes, animal, fungal and plant that were then available (Moore et al., 2005; Moore \& Meškauskas, 2006; 2009) demonstrated that there was no evidence in fungal genomes of Wnt, Hedgehog, Notch, TGF, p53, which are all crucial animal regulators, nor of the plant control sequences SINA, or NAM. Homology between the genomes of fungi and other eukaryotes was limited to 78 sequences involved in the architecture of the eukaryotic cell. Evidently, the unique cell biology of filamentous fungi has caused them to evolve control of their multicellular development in a radically different fashion from those used by animals or plants.

\section{BASIC PRINCIPLES OF FUNGAL DEVELOPMENTAL BIOLOGY}

The main features of fungal developmental biology have been summarised as a set of principles by Moore et al. (2020). The list (see below) combines most of the observations made in the pregenomics era discussed above.

It starts with the reminder that in many fungi hyphae differentiate from the vegetative form that ordinarily composes a mycelium and aggregate to form tissues of multihyphal structures; which may be linear organs that emphasise parallel arrangements of hyphae, or globose masses that emphasise interweaving of hyphae, such as sclerotia and sporophores of the larger Ascomycota and Basidiomycota.

The series of principles on which fungal morphogenesis is suggested to depend, most of which differ from both animals and plants, are as follows:

Principle 1: the fundamental cell biology of fungi on which development depends is that hyphae extend only at their apex, and cross walls form only at right angles to the long axis of the hypha.

Principle 2: fungal morphogenesis depends on the placement of hyphal branches. Increasing the number of growing tips by hyphal branching is the equivalent of cell proliferation in animals and plants. To proliferate, the hypha must branch, and to form an organised tissue the position of branch emergence and its direction of growth must be controlled.

Principle 3: the molecular biology of the management of cell-to-cell interactions in fungi is completely different from that found in animals and plants; comprehensive genome surveys found no evidence in fungal genomes sequences which are crucial animal regulators, nor of plant control sequences.

Principle 4: fungal morphogenetic programmes are organised into developmental subroutines, which are integrated collections of genetic information that contribute to individual isolated features of the programme. Execution of all the developmental subroutines at the right time and in the right place results in a normal structure. Developmental subroutines are equivalent to the transcriptional clusters, transcriptional waves of differential gene expression and differentially expressed gene sets detected in the transcriptional programme of the genome.

Principle 5: because hyphae grow only at their apex, global change to tropic reactions of all the hyphal tips in a structure is sufficient to generate basic sporophore shapes. 
Principle 6: over localised spatial scales co-ordination is achieved by an inducer hypha regulating the behaviour of a surrounding knot of hyphae and/or branches. These are called hyphal knots and they have two fates, becoming either sclerotia or sporophore initials depending on temperature and illumination (high temperature and darkness favour sclerotia; light and lowered temperature favour the sporophore pathway).

Principle 7: the response of tissues to tropic signals and the response of hyphal knots to their inducer hyphae, coupled with the absence of lateral contacts between fungal hyphae analogous to the plasmodesmata, gap junctions and cell processes that interconnect neighbouring cells in plant and animal tissues suggest that development in fungi is regulated by morphogens communicated mainly through the extracellular environment. Up-regulation of genomic transcripts in the 'extracellular matrix' category corresponds with what is known about the importance of the extracellular matrix to formation of hyphal knot which exude fluid droplets as they mature and become more condensed.

Principle 8: fungi can show extremes of cell differentiation in adjacent hyphal compartments even when pores in the cross wall appear to be open (as judged by transmission electron microscopy).

Principle 9: meiocytes appear to be the only hyphal cells that become committed to their developmental fate. Other highly differentiated cells retain totipotency - the ability to generate vegetative hyphal tips that grow out of the differentiated cell to re-establish a vegetative mycelium. Genomic analysis demonstrates that fungi, in general, have numerous genes involved in creating epigenetic marks by DNA methylation.

Principle 10: in arriving at a morphogenetic structure and/or a state of differentiation, fungi are tolerant of considerable imprecision, which results in even the most abnormal sporophores (caused by errors in execution of the developmental subroutines) being still able to distribute viable spores, with poorly (or wrongly-) differentiated cells still serving a useful function.

Principle 11: mechanical interactions influence the form and shape of the whole sporophore as it inflates and matures, and often generate the shape with which we are most familiar.

These Principles form the warp and weft of the canvas upon which fungal developmental biology has been built by the cell and molecular biologists of the pre-genomics era. It is now up to the genomic systems analysts to paint the rest of the individual details of the stories on that canvas (Kües \& Navarro-González, 2015; Kües et al., 2018; Halbwachs et al., 2016; Pelkmans et al., 2016; Hibbett et al., 2017; Stajich, 2017).

\section{RELEVANCE TO COMMERCIALLY CULTIVATED FUNGI}

We have focussed on the developmental biology of Coprinopsis cinerea in this review so far, but there are over 1000 fungal genomes listed as complete in at least draft form in the Mycocosm portal [http://igi.doe.gov/fungi]. We will end by briefly assessing the relevance of our discussion to some commercially farmed fungi, specifically: the button mushroom (Agaricus), shiitake (Lentinula), oyster mushroom (Pleurotus), and the paddy-straw mushroom (Volvariella) (Table 2).

We also include Ganoderma, which is unique in being cultivated (and consumed) for its pharmaceutical value rather than as a food. It is cultivated by being inoculated into short segments of wooden logs which are then covered in soil in an enclosure (often a plastic-covered 'tunnel') which can be kept moist and warm. The sporophores then emerge in large number quite close together and the conditions encourage the fungus to form the desirable long stemmed fruit body (Moore \& Chiu, 2001).

Recent megaphylogeny studies have determined evolutionary relationships between the clades represented by these genera. Varga et al. (2019) used multigene and genome-based data to assemble a 5,284-species phylogenetic tree with which to infer ages and patterns of speciation, 
extinction and morphological innovation in Agaricomycetes. They suggested that the subclass Agaricomycetidae diverged from other Agaricomycetes about 185 Million years ago (range 192 to174 Mya) and the Agaricales about 173 Mya (range 182 to 160 Mya). The position of the Polyporales is uncertain in this study but the clade may have diverged from the Agaricomycetes shortly before the Agaricomycetidae. He et al. (2019) compared six gene sequences in 430 species from Agaricomycotina (with six outgroup species from Pucciniomycotina) and estimated the divergence of class Agaricomycetes at 298 Mya, the Polyporales 138 Mya and Agaricales 136 Mya. Families within Agaricales were estimated to have diverged 125 Mya (Agaricaceae and Psathyrellaceae), with the Omphalotaceae (Lentinula) diverging as recently as 71 Mya.

\begin{tabular}{|c|c|c|}
\hline \multicolumn{3}{|c|}{$\begin{array}{l}\text { Table 2. URLs for genomes of commercially-traded fungi of the Class Agaricomycetes, } \\
\text { subclass: Agaricomycetidae } \\
\text { Cultivated }\end{array}$} \\
\hline $\begin{array}{l}\text { Genus (market } \\
\text { name examples) }\end{array}$ & Order Family & Mycocosm portal URL [http://igi.doe.gov/fungi] \\
\hline $\begin{array}{l}\text { Agaricus (button } \\
\text { mushroom) }\end{array}$ & $\begin{array}{l}\text { Agaricales } \\
\text { Agaricaceae }\end{array}$ & $\begin{array}{l}\text { https://mycocosm.jgi.doe.gov/mycocosm/home/releases?flt=aga } \\
\text { ricus+bisporus }\end{array}$ \\
\hline $\begin{array}{l}\text { Coprinopsis (ink } \\
\text { cap) }\end{array}$ & $\begin{array}{c}\text { Agaricales } \\
\text { Psathyrellaceae }\end{array}$ & $\begin{array}{l}\text { https://mycocosm.jgi.doe.gov/mycocosm/home/releases?flt=cop } \\
\text { rinopsis+cinerea }\end{array}$ \\
\hline $\begin{array}{l}\text { Ganoderma } \\
\text { (reishi/ lingzhi) }\end{array}$ & $\begin{array}{c}\text { Polyporales } \\
\text { Ganodermataceae }\end{array}$ & https://mycocosm.jgi.doe.gov/Gansp1/Gansp1.home.html \\
\hline $\begin{array}{l}\text { Lentinula } \\
\text { (shiitake) }\end{array}$ & $\begin{array}{c}\text { Agaricales } \\
\text { Omphalotaceae }\end{array}$ & $\begin{array}{l}\text { https://mycocosm.jgi.doe.gov/mycocosm/home/releases?flt=Len } \\
\text { tinula+edodes }\end{array}$ \\
\hline $\begin{array}{l}\text { Pleurotus (oyster } \\
\text { mushroom) }\end{array}$ & $\begin{array}{l}\text { Agaricales } \\
\text { Pleurotaceae }\end{array}$ & $\begin{array}{l}\text { https://mycocosm.jgi.doe.gov/mycocosm/home/releases?flt=Ple } \\
\text { urotus+ostreatus }\end{array}$ \\
\hline $\begin{array}{l}\text { Volvariella (straw } \\
\text { mushroom) }\end{array}$ & $\begin{array}{l}\text { Agaricales } \\
\text { Pluteaceae }\end{array}$ & $\begin{array}{l}\text { https://mycocosm.jgi.doe.gov/mycocosm/home/releases?flt=Vol } \\
\text { variella+volvacea }\end{array}$ \\
\hline \multicolumn{3}{|c|}{$\begin{array}{l}\text { Other edible mushrooms with massive world-wide markets (amounting to billions of dollars } \\
\text { annually) are field-collected mycorrhizal species }\end{array}$} \\
\hline $\begin{array}{l}\text { Cantharellus } \\
\text { cibarius } \\
\text { (chanterelle) }\end{array}$ & $\begin{array}{l}\text { Cantharellales } \\
\text { Cantharellaceae }\end{array}$ & $\begin{array}{l}\text { https://mycocosm.jgi.doe.gov/mycocosm/home/releases?flt=Can } \\
\text { tharellus }\end{array}$ \\
\hline $\begin{array}{l}\text { Boletus edulis } \\
\text { (cep, penny bun } \\
\text { or porcini) }\end{array}$ & $\begin{array}{l}\text { Boletales } \\
\text { Boletaceae }\end{array}$ & $\begin{array}{l}\text { https://mycocosm.jgi.doe.gov/mycocosm/home/releases?flt=Bol } \\
\text { etus+edulis }\end{array}$ \\
\hline $\begin{array}{l}\text { Tricholoma } \\
\text { matsutake } \\
\text { (matsutake). }\end{array}$ & $\begin{array}{c}\text { Agaricales } \\
\text { Tricholomataceae }\end{array}$ & $\begin{array}{l}\text { https://mycocosm.jgi.doe.gov/mycocosm/home/releases?flt=Tric } \\
\text { holoma+matsutake }\end{array}$ \\
\hline
\end{tabular}

In the following paragraphs we mention a few of the more recent 'omics' publications that deal with what we believe to be significant themes in current research on the five most commonly farmed Agaricomycetes. We also point out a few research themes worthy of closer attention.

Agaricus. In the last century, Loftus et al. (1988) demonstrated that restriction fragment length polymorphisms (RFLPs) had great potential in the development of the genetics and breeding of Agaricus bisporus by providing the basis for genetic finger-printing, differentiating between homokaryons and heterokaryons and following gene segregations in crosses.

Earlier this century an international group of scientists from seven countries completed the sequencing and initial analysis of the Agaricus bisporus genome [see http://www.emr.ac.uk/projectposts/agaricusgenome-project/] (Morin et al., 2012). They reported a genome of around 30 million bases spread across thirteen chromosomes. An alignment with Coprinopsis cinerea showed considerable synteny. Further analyses of the $A$. bisporus genome and transcriptome revealed the necessary genes for the degradation of polymers found in plant litter (specifying enzymes able to digest lignin, cellulose, 
hemicellulose and proteins; see Chapter 11 in Moore et al., 2020). However, Agaricus grows poorly on plant litter unless it is already partially decomposed, which is why in the European tradition mushroom farming has come to mean cultivation of a mushroom crop on composted plant litter (Junior Letti et al., 2018). Production of compost for mushroom farming has become a self-contained industry, and mushroom farms depend on highly selective substrate, with defined levels of ammonia, protein, $\mathrm{pH}$ and moisture. Although widely distributed in nature, A. bisporus can be difficult to find. However, one ecological niche, now well known, is the litter of cypress trees (Arora, 1986). Today's industry can be viewed as a 'joint evolution' of substrate and cultivar, resulting in high cropping densities by an otherwise unremarkable and not very abundant mushroom (Buth, 2017; and see Section 12.6 in Moore et al., 2020).

Transcriptome analysis provides a molecular explanation of Agaricus biology compared to other woodor leaf- degrading fungi. In particular, $A$. bisporus has a large number of genes specifying enzymes able to metabolise the breakdown products of lignin, and these genes are upregulated in the presence of partially decomposed plant litter. Partially decomposed materials are called humic substances; these being naturally occurring organic compounds resulting from the decomposition and transformation of plant, animal, and microbial residues. They are important components of humus, which is the major organic fraction of soil. The demonstration by the transcriptome analysis of gene composition and expression profiles that $A$. bisporus is highly specialised to a humic-rich substrate led to the conjecture that the behaviour might be regulated by a new humic response promoter element (Kerrigan et al., 2013).; These authors also proposed the category humicolous as a new econutritional classification that expands lignocellulosic digestion categories beyond white-rot fungi (that break down the lignin in wood, leaving the lighter-coloured cellulose behind, though some digest both lignin and cellulose) and brown-rot fungi (that break down hemicellulose and cellulose, leaving the lignin) (and see Riley et al., 2014).

It is interesting to recall that Wood (1980) demonstrated that during mycelial growth of Agaricus bisporus, a large proportion of the compost lignin was degraded, and correspondingly high activities of laccase were recorded (this one enzyme could amount to $2 \%$ of the total fungal protein). Yet, as the culture formed sporophores laccase activity was rapidly lost, initially by inactivation and subsequently by proteolysis; this pattern of behaviour reflecting the changing nutritional demands of fungal mycelia as they process through successive developmental phases and the ability of the mycelium to act on its environment to satisfy those demands.

Agaricus bisporus is globally distributed and a substantial collection of wild-collected strains is available (Sonnenberg et al., 2017). Such collections provide opportunities for directed breeding (O'Connor et al., 2019) of button mushrooms as genomics analysis improves understanding of relationships with disease organisms (Bailey et al., 2013), and potential for improvement of stress resistance (Sun et al., 2019) and other improved agronomic characteristics.

Ganoderma. Under the names lingzhi or reishi, Ganoderma lucidum is a cultivated mushroom which is unique in being consumed for its pharmaceutical value (real or imagined) rather than as a food. Ganoderma is highly regarded as a traditional herbal medicine, though many of the claims made for it are clinically unproven. Several species of the G. Iucidum complex provide various commercial brands of nutriceuticals, in the form of health drinks, powders, tablets, capsules and diet supplements. Current research is focussed on purification and characterisation of the bioactive components and determination of clinical value, especially putative anti-tumour and anti-aging properties.

The morphology of Ganoderma sporophores varies greatly and at least some of that variation is likely to be due to misidentifications as the taxonomy of the Ganoderma lucidum complex has been described as 'chaotic'. Analysis of 32 collections of the complex from Asia, Europe and North America using both morphology and molecular phylogenetics recovered a total of 13 taxonomically distinct species within the complex (Zhou et al., 2015). In sharp contrast, a survey of the molecular phylogenetics of 20 specimens of the related clade, Ganoderma sinense, from China were found to 
exhibit varied sporophore morphology, even though they possessed identical nucleotide sequences (Hapuarachchi et al., 2019). Evidently, phenotypic plasticity (= varied sporophore morphology) of a specimen or strain of Ganoderma can be influenced greatly by extrinsic factors, such as climate, nutrition, vegetation, and geographical environment rather than being necessarily associated with genotypic variation.

Ganoderma is mainly farmed for use as a traditional Chinese medicine; well over 400 secondary metabolites have been isolated from various Ganoderma species (Baby et al., 2015; Ahmad, 2019; Zhou et al., 2018). Triterpenoids and polysaccharides are the two major categories of pharmacologically active compounds in Ganoderma lucidum. A mixture of G. lucidum polysaccharides (known as GLP) is the main bioactive component in water-soluble extracts of the mushroom, and there is some evidence that GLP possesses potential anticancer activity (Sohretoglu \& Huang, 2018). These metabolites influence the patient's innate and adaptive immune system, resulting in therapeutic immune modification (Berovič \& Podgornik, 2015; Wang et al., 2017; Sudheer et al., 2018). Other metabolites found in extracts of Ganoderma have been found to be stimulators of neural stem cell proliferation in vitro and could be valuable treatments for neurodegenerative diseases (Yan et al., 2015). In addition to producing these bioactive chemicals, G. lucidum is a white rot fungus, secreting enzymes that can decompose both cellulose and lignin. Genome sequence analysis (Chen et al., 2012) has revealed the impressive array of genes encoding cytochromes, transporters and regulatory proteins that cooperate in this secondary metabolism in G. lucidum and prepare the way for the metabolomics that will further exploit it (Bhardwaj et al., 2017; Ma et al., 2018). Initial genomic studies of the related Ganoderma australe, which is a widespread and common tree pathogen in the British Isles and mainland Europe, also reveal considerable biotechnological potential (Agudelo-Valencia et al., 2020).

Another species of Ganoderma of major global significance is $G$. boninense, which causes basal stem rot disease of oil palm. The genome sequence of this species has been reported (Utomo et al., 2019) and an environmentally-friendly potential necrotrophic mycoparasite (Scytalidium parasiticum; Ascomycota) has been identified as a potential candidate for biocontrol of this disease in oil palm, there being no other effective treatments (Goh et al., 2016).

Lentinula. Generally known by its common (Japanese) name shiitake, Lentinula edodes is one of the most popular edible mushroom species, second only in production volume to Agaricus. It is widely cultivated in many Asian countries, especially China, Japan and Korea and is increasingly penetrating the markets in Australia, Europe, and the USA. It is a white rot fungus with highly developed lignocellulose degradation ability and is consequently widely distributed as a member of the wooddecay community (Chiu et al., 1999). Shiitake mushrooms are also the source of polysaccharides with verified immunomodulatory activity; Lentinan is a $\beta-1,3$-glucan with $\beta-1,6$ branching and a molecular weight of $500,000 \mathrm{Da}$, which has been used in several clinical trials in cancer patients, though welldesigned large-scale studies are still lacking [view: https://www.mskcc.org/cancer-care/integrativemedicine/herbs/lentinan].

Chen et al. (2016b) report the genome sequence of Lentinula edodes and initiate the transcriptome analysis of the expression of genes encoding cellulases and transcription factors up-regulated when mycelia were briefly cultivated in cellulose medium versus glucose medium. Their aim is to understand the molecular mechanism of lignocellulose degradation sufficiently to allow partial replacement of wood sawdust with agricultural wastes in L. edodes cultivation.

Transcriptome analysis has also been done to study postharvest problems in $L$. edodes, such as gill browning, sporophore softening, and lentinan degradation, and including light-induced browning (Sakamoto et al., 2017; Yoo et al., 2019). These analyses revealed a rapid sporophore autolysis system in L. edodes, with many cell wall-degrading enzymes being upregulated after harvest, along with many transcription factor genes. Clusters of genes specific to light-induced browning were associated with photoreceptors and melanogenesis via activation of tyrosinases, as well as cell wall 
degradation enzyme systems. These studies also found that several cell death related proteins were also upregulated postharvest.

This last observation is interesting because senescence and cell death are important aspects of the biology of fungi just as they are in the other two major eukaryotic kingdoms (Shefferson et al., 2017). Removal of old individuals makes way for the young and allows populations to evolve, but in individual multicellular organisms, programmed cell death (PCD), which is the removal of tissue in a manner controlled in time and position, is a crucial contributor to morphogenesis in all eukaryotes. There are two types of cell death: traumatic or necrotic death and apoptosis or programmed cell death. In higher animals PCD involves a sequence of well-regulated processes, which lead to eventual removal of the dying cell by phagocytosis. It is important that elimination of cells is intracellular in higher animals to avoid escape of antigens and the consequent danger of autoimmunity. This is not a consideration in plants and fungi. Indeed, in fungi the evidence is that the developmental programme leading to cell death involves sacrificing cells by over-producing proteins and mucilaginous materials appropriate to the new structure which are released by lysis of the cell. In fungal PCD the cell contents released when the sacrificed cells die are specialised to particular functions (discussion in Section 13.15 in Moore et al., 2020). Unfortunately, there is only one experimental study of the longevity of fungal sporophores. Umar \& Van Griensven (1997a, 1997b, 1998) studied the senescence and death of sporophores of Agaricus bisporus by growing the cultivated mushroom in artificial environments which protected the culture from pests and diseases. They found that the life span of sporophores of $A$. bisporus was 36 days, though ageing was first evident in sporophores about 18 days old, when localised nuclear and cytoplasmic lysis was seen. After 36 days most of the cells in the mushroom were severely degenerated and malformed. Nevertheless, a few basidia and subhymenial cells were alive and cytologically intact even on day 36. So even in severely senescent sporophores healthy, living cells were found. We suggest that senescence and death of Lentinula sporophores would be a suitable topic for genomic analysis so that the postharvest findings can be understood in their natural biological context (Wiemer et al., 2016).

Another aspect we suggest worthy of transcriptomic/metabolomic analysis is the accumulation in Agaricus bisporus and Lentinula edodes of the sugar alcohol mannitol, which is synthesised to serve an osmoregulatory function. For comparison, mannitol alone can amount to as much as $50 \%$ of the total mushroom dry weight in Agaricus bisporus, and $20-30 \%$ in L. edodes (Hammond \& Nichols, 1976; Tan \& Moore, 1994). Enzymes of the pentose phosphate pathway, though always at low activity in mycelium, are specifically elevated by a factor of about 15 times in the shiitake mushroom (Tan \& Moore, 1995).

Pleurotus. The genus Pleurotus includes several species of commercial value, such as $P$. ostreatus, $P$. pulmonarius, $P$. cornucopiae, $P$. eryngii, $P$. ostreatoroseus, and $P$. sajor caju, among others. Pleurotus mushrooms are distributed globally and have been cultivated in different parts of the world, ranking second in the world mushroom market (Bellettini et al., 2019). These fungi are white-rot fungi that secrete enzymes able to degrade lignin present in lignocellulosic substrates. Pleurotus enzymatic machinery is able to degrade complex compounds, constituting a great tool for the bioremediation of polluted environments. Genome sequencing has recently revealed the wood-degrading machinery of $P$. ostreatus to be typical of white rot fungi (Riley et al. 2014). P. ostreatus is the most cultivated species of the genus. This fungus is also known as 'oyster mushroom' or 'grey oyster mushroom' to distinguish it from other Pleurotus species. In Asian countries, it is also called 'hiratake', 'shimeji', or 'houbitake'. Several studies have shown that $P$. ostreatus has medicinal properties and potential biotechnological applications. It has been shown to produce pleuran, a bioactive glucan which has immunomodulatory and antioxidant properties. Pleuran has $\beta(1,4)$ - or $\beta(1,6)$-branches at every fourth residue in its $\beta(1,3)$-glucan backbone (Sánchez, 2017a; 2017b). On the other hand, $P$. ostreatus is one of the carnivorous mushrooms known to be capable of killing and digesting nematodes as a nitrogen source, which raises interest in them as biocontrol agents as alternatives to conventional nematicides which have a negative impact on the global ecosystem (Thorn \& Barron 1984, Thorn et al. 2000; Balaeș \& Tănase, 2016). Chiu et al. (1998) and Sadiq et al. (2019) reported that the spent 
mushroom compost of $P$. pulmonarius and $P$. ostreatus was able to degrade toxic organic pollutants such as pentachlorophenol and endosulfan, pesticides reported to be carcinogenic. Ahuactzin-Pérez et al. (2018) found that $P$. ostreatus degrades and uses as carbon and energy source high concentration $(1000 \mathrm{mg} / \mathrm{L})$ of di(2-ethyl hexyl) phthalate, which is a plasticizer that interfere with endocrine systems in mammals and has been detected as contaminant in the environment. The potential for using Pleurotus for pollutant and plastic degradation is discussed by Sánchez et al. (2020).

The demand for improved Pleurotus strains with high productive capacity has been rising. Currently, new generation approaches such as molecular breeding, genetic transformation and genome editing are used for strain improvement (Barh et al., 2019). So far, seven species of Pleurotus ( $P$. ostreatus, $P$. platypus, $P$. citrinopileatus, $P$. salmoneo-stramineus, $P$. eryngii, $P$. tuber-regium and $P$. tuoliensis) have been sequenced, having genome sizes between 33. $5 \mathrm{MB}$ and 49.9 MB (Barh et al., 2019). Comparative genome sequence analysis showed that the sizes of $P$. eryngii (49.92 MB) and $P$. tuoliensis (48.23 MB) genome are significantly larger than other Pleurotus species, mainly due to their higher percentage of transposable elements and high long-terminal repeat transposable elements (Zhang et al. 2018). These transposable elements have epigenetic roles and cause silencing in Pleurotus genomes (Borgognone et al. 2018). Gao et al. (2018) reported the first genetic linkage map integrated with physical mapping of the de novo sequenced genome and the mating type loci of $P$. tuoliensis. This is an important cultivated mushroom in China, where commercial profits are low, mainly due to a long cultivation period, sensitivity to diseases and a low yield. The de novo sequenced and annotated genome, assembled using a 2b-RAD (Restriction site $\underline{\text { Associated }} \underline{\mathrm{D}} \mathrm{NA}$ ) generated linkage map, provides a basis for marker-assisted breeding of this mushroom, which is crucial to improve agronomically-important traits. The $2 b-R A D$ method uses type IIB restriction enzymes to generate a restriction-site associated library (Wang et al., 2012). This information and other research findings on genetic improvement are crucial in future breeding programs.

Volvariella. Breeding of improved strains in Volvariella volvacea has been hampered by its ambiguous sexuality pattern so it is in this aspect that genomic analysis could make the greatest contribution. Vegetative hyphal compartments of $V$. volvacea, and the hyphae of sporophore tissues are multinucleate and their septa lack clamp connections. An apparently normal meiosis occurs with DNA replication taking place at prophase I of meiosis in basidia that form four basidiospores into which the four meiotic nuclei migrate individually. The basidiospores remain uninucleate as there is no post-meiotic mitosis until germination (Chiu, 1993). As long ago as 1987, Royse et al. demonstrated Mendelian segregation of five allozyme loci in $V$. volvacea. Further, there seems to be no barrier to cross-fertility, with no evidence for the expression of mating type genes. On the other hand, although the overwhelming majority of the basidiospores are uninucleate, many of these uninucleate basidiospores germinate to form mycelia which are self-fertile and able to form sporophores. In many cases, tests for self-fertility showed a 1:1 ratio of self-fertile to self-sterile among progenies. Even more unusual is that published evidence shows that progenies resulting from selfing in $V$. volvacea are regularly phenotypically diverse, implying that the selfed diploid that enters meiosis is not homozygous (see discussion and references in Chiu \& Moore, 1999).

After considering likely mechanisms for generating genetic variation, Chiu \& Moore (1999) suggested that a plausible mechanism, which could generate variation and produce 1:1 ratios from initially heterozygous loci, might be to regulate meiotic recombination mechanisms such that repair of base mismatches in hybrid DNA is reduced or eliminated. The result would be that (a) in every meiosis at least a proportion of the heterozygosity of the diploid nucleus would be preserved in the haploid daughter nuclei in the form of base mismatches in hybrid DNA; (b) at the first postmeiotic mitosis (at germination) these mismatches would be segregated into daughter nuclei and the $V$. volvacea spore germling would immediately become dikaryotic, even though the basidiospore had a single haploid nucleus; (c) assuming that recombination and mismatch-repair patterns differed between meioses then different spores would produce different dikaryons; (d) if half the base-mismatches at an initially heterozygous hypothetical fertility locus were repaired prior to the post-meiotic mitosis then a 1:1 ratio 
could result of self-fertile (still heterozygous in the sporeling dikaryon): self-sterile (repaired to homozygosity).

Analyses of the Volvariella genome are beginning to resolve some of these issues. Bao et al. (2013) reported the mating type system of $V$. volvacea to be similar to the bipolar system in basidiomycetes, suggesting that the organism might be secondarily homothallic. Chen et al. (2016a) studied the life cycle of $V$. volvacea using whole genome sequencing; demonstrating that the heterothallic life cycle is bipolar, as MAT-A, and not MAT-B, controlled heterokaryotization. They cloned the MAT loci and found MAT locus polymorphisms in a series of strains. Crosses performed to establish the role(s) of the different MAT loci in mating established the presence of three coexisting, homo- and heterothallic life cycles. This study confirmed all of the peculiarities in segregation patterns previously demonstrated decades before with allozymes, colony morphology markers, restriction fragment length polymorphisms and electrophoretic karyotypes described in the previous paragraph. Also, the demonstration of structural variation (SV) markers relating to both alleles of both parents in single spore isolates that were clearly not heterokaryotic, and doubled SV markers in large numbers of single spore isolates suggested that the DNA structural peculiarities hypothesised by Chiu \& Moore (1999) remained plausible.

Despite these numerous peculiarities Bao \& Wang (2016) have established an efficient molecular marker-assisted cross-breeding technique for generating improved Volvariella volvacea cultivars. Whilst He et al. (2018) used a protoplast fusion technique to make interfamily hybridisations between $V$. volvacea and Pleurotus eryngii in attempts to improve the low-temperature tolerance and biological efficiency of Volvariella. Their hybrid strains showed higher biological efficiency (31.5\%), compared with the $9.4 \%$ of the parental strain, and longer storage life at $16^{\circ} \mathrm{C}$. The authors suggest that protoplast fusion provides an effective way to hybridise distantly-related edible fungi.

\section{REFERENCES}

Agudelo-Valencia D., Uribe-Echeverry P.T. \& Betancur-Pérez J.F. 2020. De novo assembly and annotation of the Ganoderma australe genome. Genomics. 112(1): 930-933. DOI: https://doi.org/10.1016/j.ygeno.2019.06.008.

Ahmad M.F. 2019. Ganoderma lucidum: a macro fungus with phytochemicals and their pharmacological properties. In Plant and Human Health, Vol. 2, ed. M. Ozturk \& K. Hakeem. Cham, Switzerland: Springer Nature, pp. 491-515. ISBN: 9783030033439. DOI: https://doi.org/10.1007/9783-030-03344-6 21.

Ahmed Y.L., Gerke J., Park H.-S., Bayram Ö., Neumann P. and six others. 2014. The Velvet family of fungal regulators contains a DNA-binding domain structurally similar to NF-kB. PLoS Biology. 11: article number e1001750. DOI: https://doi.org/10.1371/journal.pbio.1001750.

Ahuactzin-Pérez M., Tlecuitl-Beristain S., García-Dávila J., Santacruz-Juárez E., González-Pérez M., Gutiérrez-Ruíz M. C. \& Sánchez C. 2018. A novel biodegradation pathway of the endocrine-disruptor di(2-ethylhexyl) phthalate by Pleurotus ostreatus based on quantum chemical investigation. Ecotoxicology Enviromental Safety. 147: 494-499. DOI: https://doi.org/10.1016/j.ecoenv.2017.09.004.

Allen J.J., Moore D. \& Elliott T.J. 1992. Persistent meiotic arrest in basidia of Agaricus bisporus. Mycological Research. 96: 125-127. DOI: https://doi.org/10.1016/S0953-7562(09)80926-X.

Andrews J.H. 1995. Fungi and the evolution of growth form. Canadian Journal of Botany. 73: S1206S1212. DOI: https://doi.org/10.1139/b95-380.

Arora D. 1986. Mushrooms Demystified (2nd edition). Berkeley, CA: Ten Speed Press. 102 pp. ISBN: 9780898151695.

Baby S., Johnson A.J. \& Govindan B. 2015. Secondary metabolites from Ganoderma. Phytochemistry. 114: 66-101. DOI: https://doi.org/10.1016/i.phytochem.2015.03.010. 
Bailey A.M., Collopy P.D., Thomas D.J., Sergeant M.R., Costa A.M.S.B., Barker G.L.A. Mills P.R., Challen M.P., Foster G.D. 2013. Transcriptomic analysis of the interactions between Agaricus bisporus and Lecanicillium fungicola. Fungal Genetics and Biology. 55: 67-76. DOI: https://doi.org/10.1016/i.fglb.2013.04.010.

Balaeș T. \& Tănase C. 2016. Basidiomycetes as potential biocontrol agents against nematodes. Romanian Biotechnological Letters. 21(1): 11185-11193. Romanian Biotechnological Letters 21(1):11185. URL: https://e-repository.org/rbl/vol.21/iss.1/13.pdf.

Bao D., Gong M., Zheng H., Chen M., Zhang L. et al. 2013. Sequencing and comparative analysis of the straw mushroom (Volvariella volvacea) genome. PLoS ONE. 8(3): article number e58294. DOI: http://dx.doi.org/10.1371/journal.pone.0058294.

Bao D. \& Wang H. 2016. Identification and application of Volvariella volvacea mating type genes to mushroom breeding. In: Mushroom Biotechnology: Developments and Applications, (ed Petre, M.). Chapter 11, pp. 191-201. Amsterdam: Academic Press, an imprint of Elsevier Inc. DOI: https://doi.org/10.1016/B978-0-12-802794-3.00011-4.

Barh A., Sharma,V. P. Annepu S. K., Kamal S., Sharma S. \& Bhatt P. 2019. Genetic improvement in Pleurotus (oyster mushroom): a review. 3 Biotech. 9(9): article number 322. DOI: https://doi.org/10.1007/s13205-019-1854-x.

Bastouill-Descollonges Y. \& Manachère G. 1984. Photosporogenesis of Coprinus congregatus: correlations between the physiological age of lamellae and the development of their potential for renewed fruiting. Physiologia Plantarum. 61: 607-610. DOI: https://doi.org/10.1111/j.13993054.1984.tb05177.x.

Bayram Ö., Krappmann S., Ni M., Bok J.W., Helmstaedt K., and six others. 2008. VelB/VeA/LaeA complex coordinates light signal with fungal development and secondary metabolism. Science. 320: 1504-1506. DOI: https://doi.org/10.1126/science.1155888.

Bellettini M.B., Fiorda F.A., Maieves H.A., Teixeira G.L., Ávila S., Hornung P.S., Júnior A.M. \& Ribani R.H. 2019. Factors affecting mushroom Pleurotus spp. Saudi Journal of Biological Sciences. 26(4): 633-646. DOI: https://doi.org/10.1016/i.sibs.2016.12.005.

Berne S., Pohleven J., Vidic I., Rebolj K., Pohleven F., Turk T., Macek P., Sonnenberg A. \& Sepčić K. 2007. Ostreolysin enhances fruiting initiation in the oyster mushroom (Pleurotus ostreatus). Mycological Research. 111(12): 1431-1436. DOI: https://doi.org/10.1016/i.mycres.2007.09.005.

Berovič M. \& Podgornik B.B. 2015. Cultivation of medicinal fungi in bioreactors. In Mushroom Biotechnology: Developments and Applications, ed. M. Petre. London: Academic Press, an imprint of Elsevier Inc, pp. 155-171. ISBN: 9780128027943. DOI: https://doi.org/10.1016/B978-0-12-8027943.00009-6.

Bhardwaj A., Gupta P., Kumar N., Mishra J., Kumar A., Rakhee R. \& Misra K. 2017. Lingzhi or reishi medicinal mushroom, Ganoderma lucidum (Agaricomycetes), inhibits Candida biofilms: a metabolomic approach. International Journal of Medicinal Mushrooms. 19(8): 685-696. DOI: http://dx.doi.org/10.1615/IntJMedMushrooms.2017021225.

Bleuler-Martínez S., Butschi A., Garbani M., Wälti M.A., Wohlschlager T. and seven others. 2011. A lectin-mediated resistance of higher fungi against predators and parasites. Molecular Ecology. 20: 3056-3070. DOI: https://doi.org/10.1111/j.1365-294X.2011.05093.x.

Bobola N. \& Merabet S. 2017. Homeodomain proteins in action: similar DNA binding preferences, highly variable connectivity. Current Opinion in Genetics \& Development. 43: 1-8. DOI: https://doi.org/10.1016/i.gde.2016.09.008. 
Borgognone A., Castanera R., Morselli M., Lopez-Varas L., Rubbi L., Pisabarro A. G., Pellegrini M. \& Ramirez L. 2018. Transposon associated epigenetic silencing during Pleurotus ostreatus life cycle. DNA Research. 25(5): 451-464. DOI: https://doi.org/10.1093/dnares/dsy016.

Burns C., Stajich J.E., Rechtsteiner A., Casselton L.A., Hanlon S.E., Wilke S.K., Savytskyy O.P., Gathman A.C., Lilly W.W., Lieb J.D., Zolan M.E. \& Pukkila, P.J. 2010. Analysis of the basidiomycete Coprinopsis cinerea reveals conservation of the core meiotic expression program over half a billion years of evolution. PLOS Genetics. 6: article number e1001135. DOI: https://doi.org/10.1371/journal.pgen.1001135.

Bush D.A. 1974. Autolysis of Coprinus comatus sporophores. Experientia. 30: 984-985. DOI: https://doi.org/10.1007/BF01938959.

Buth J. 2017. Compost as a food base for Agaricus bisporus. In: Edible and Medicinal Mushrooms: Technology and Applications, (eds D.C. Zied \& A. Pardo-Giménez), pp. 129-148. Chichester, UK: John Wiley \& Sons (Wiley-Blackwell). DOI: https://doi.org/10.1002/9781119149446.ch6.

Butler G.M. 1988. Pattern of pore morphogenesis in the resupinate basidiome of Phellinus contiguus. Transactions of the British Mycological Society. 91: 677-686. DOI: https://doi.org/10.1016/S00071536(88)80044-5.

Butler G.M. 1992a. Location of hyphal differentiation in the agar pore field of the basidiome of Phellinus contiguus. Mycological Research. 96: 313-317. DOI: https://doi.org/10.1016/S09537562(09)80944-1.

Butler G.M. 1992b. Capacity for differentiation of setae and other hyphal types of the basidiome in explants from cultures of the polypore Phellinus contiguus. Mycological Research. 96: 949-955. DOI: https://doi.org/10.1016/S0953-7562(09)80596-0.

Butler G.M. 1995. Induction of precocious fruiting by a diffusible sex factor in the polypore Phellinus contiguus. Mycological Research. 99: 325-329. DOI: https://doi.org/10.1016/S0953-7562(09)80907-6.

Butler G.M. \& Wood A.E. 1988. Effects of environmental factors on basidiome development in the resupinate polypore Phellinus contiguus. Transactions of the British Mycological Society. 90: 75-83. DOI: https://doi.org/10.1016/S0007-1536(88)80182-7.

Chan K.P., Chang J., Xie Y., Cheung M.K., Ma K.L. \& Kwan H.S. 2018. Transcriptional profiling elucidates the essential role of glycogen synthase kinase 3 to fruiting body formation in Coprinopsis cinerea. Cold Spring Harbor Laboratory preprint service bioRxiv: article 492397. DOI: https://doi.org/10.1101/492397.

Chang J., Au C.H., Cheng C.K. \& Kwan H.S. 2018a. eQTL network analysis reveals that regulatory genes are evolutionarily older and bearing more types of PTM sites in Coprinopsis cinerea. Cold Spring Harbor Laboratory preprint service bioRxiv: article 413062. DOI: https://doi.org/10.1101/413062.

Chang J., Chan K.P., Xie Y., Ma K.L. \& Kwan H.S. 2018b. Modified recipe to inhibit GSK-3 for the living fungal biomaterial manufacture. Cold Spring Harbor Laboratory preprint service bioRxiv: article 496265. DOI: https://doi.org/10.1101/496265.

Chang S.T. \& Hayes W.A. 1978. The Biology and Cultivation of Edible Mushrooms. New York: Academic Press. 842 pp. ISBN: 9780121680503. DOI: https://doi.org/10.1016/C2013-0-10484-9.

Chang S.T. \& Miles P.G. 1989. Edible Mushrooms and their Cultivation. Boca Raton, FLA: CRC Press Inc. 345 pp. ISBN: 9780849367588.

Chang S.T. \& Miles P.G. 2004. Mushrooms: cultivation, nutritional, medicinal effect and environmental impact. Second ed., CRC Press, London. 316 pp. ISBN: 9780849310430. 
Chavez L., Huang Y., Luong K., Agarwal S., Iyer L.M. and twelve others. 2014. Simultaneous sequencing of oxidized methylcytosines produced by TET/JBP dioxygenases in Coprinopsis cinerea. Proceedings of the National Academy of Sciences of the United States of America. 111: E5149E5158. DOI: https://doi.org/10.1073/pnas.1419513111.

Chen B., van Peer A.F., Yan J., Li X., Xie B. et al. 2016a. Fruiting body formation in Volvariella volvacea can occur independently of its MAT-A-controlled bipolar mating system, enabling homothallic and heterothallic life cycles. G3: Genes, Genomes, Genetics. 6 (7): 2135-2146. DOI: http://dx.doi.org/10.1534/g3.116.030700.

Chen L., Gong Y., Cai Y., Liu W., Zhou Y., Xiao Y. et al. 2016b. Genome sequence of the edible cultivated mushroom Lentinula edodes (shiitake) reveals insights into lignocellulose degradation. PLoS ONE. 11(8): e0160336. DOI: http://dx.doi.org/10.1371/journal. pone.0160336.

Chen S., Xu J., Liu C., Zhu Y., Nelson D.R. et al. 2012. Genome sequence of the model medicinal mushroom Ganoderma lucidum. Nature Communications, 3: article number: 913. DOI: https://doi.org/10.1038/ncomms1923Abstract.

Cheng C.K., Au C.H., Wilke S.K., Stajich J.E., Zolan M.E. Pukkila, P.J. \& Kwan H.S. 2013. 5'-serial analysis of gene expression studies reveal a transcriptomic switch during fruiting body development in Coprinopsis cinerea. BMC Genomics. 14: 195 (17 pages). DOI: https://doi.org/10.1186/1471-2164-14195.

Cheng W., Zhang X. \& Wang W. 2016. Robust methods for expression quantitative trait loci mapping. In: Big Data Analytics in Genomics (K.C. Wong, ed.). Cham, Switzerland: Springer International Publishing. ISBN: 978-3-319-41278-8. DOI: https://doi.org/10.1007/978-3-319-41279-5 2.

Chiu S.W. 1993. Evidence for a haploid life-cycle in Volvariella volvacea from microspectrophotometric measurements and observations of nuclear behaviour. Mycological Research. 97: 1481-1485. DOI: https://doi.org/10.1016/S0953-7562(09)80221-9.

Chiu S. W., Ching M. L., Fong K. L. \& Moore, D. 1998. Spent Oyster mushroom substrate performs better than many mushroom mycelia in removing the biocide pentachlorophenol. Mycological Research, 102: 1553-1562. DOI: https://doi.org/10.1017/S0953756298007588.

Chiu S.W. \& Moore D. 1988a. Evidence for developmental commitment in the differentiating fruit body of Coprinus cinereus. Transactions of the British Mycological Society. 90: 247-253. DOI: https://doi.org/10.1016/S0007-1536(88)80096-2.

Chiu S. W. \& Moore D. 1988b. Ammonium ions and glutamine inhibit sporulation of Coprinus cinereus basidia assayed in vitro. Cell Biology International Reports. 12: 519-526. DOI: https://doi.org/10.1016/0309-1651(88)90038-0.

Chiu S.W. \& Moore D. 1990a. A mechanism for gill pattern formation in Coprinus cinereus. Mycological Research. 94: 320-326. DOI: https://doi.org/10.1016/S0953-7562(09)80357-2.

Chiu S.W. \& Moore D. 1990b. Development of the basidiome of Volvariella bombycina. Mycological Research. 94: 327-337. DOI: https://doi.org/10.1016/S0953-7562(09)80358-4.

Chiu S.W. \& Moore D. 1990c. Sporulation in Coprinus cinereus: use of an in vitro assay to establish the major landmarks in differentiation. Mycological Research. 94: 249-253. DOI: https://doi.org/10.1016/S0953-7562(09)80623-0.

Chiu S.W. \& Moore D. 1999. Segregation of genotypically diverse progeny from self-fertilized haploids of the Chinese straw mushroom, Volvariella volvacea. Mycological Research. 103: 1335-1345. DOI: http://dx.doi.org/10.1017/S0953756299001422.

Chiu S.W., Moore D. \& Chang S.T. 1989. Basidiome polymorphism in Volvariella bombycina. Mycological Research. 92: 69-77. DOI: https://doi.org/10.1016/S0953-7562(89)80098-X. 
Chiu S. W., Wang Z. M., Chiu W. T., Lin F. C. \& Moore D. 1999. An integrated study of individualism in Lentinula edodes in nature and its implication for cultivation strategy. Mycological Research. 103: 651660. DOI: http://dx.doi.org/10.1017/S095375629900859X.

Corner E.J.H. 1932. A Fomes with two systems of hyphae. Transactions of the British Mycological Society. 17: 51-81. DOI: https://doi.org/10.1016/S0007-1536(32)80026-4.

Corner E.J.H. 1966. A monograph of cantharelloid fungi. Annals of Botany Memoirs no. 2. Oxford, UK: Oxford University Press. 255 pp. ISBN: 9780199200214.

Cuomo C.A. \& Birren B.W. 2010. The Fungal Genome Initiative and lessons learned from genome sequencing. In: Guide to Yeast Genetics: Functional Genomics, Proteomics, and Other Systems Analysis, (eds J. Weissman, C. Guthrie \& G.R. Fink). Methods in Enzymology. Volume 470, pp. 833855. San Diego, USA: Academic Press, an imprint of Elsevier. DOI: https://doi.org/10.1016/S00766879(10)70034-3.

Doudna J.A. \& Sontheimer E.J. (eds) 2014. The Use of CRISPR/Cas9, ZFNs, and TALENs in Generating Site-Specific Genome Alterations. Methods in Enzymology. Volume 546. San Diego, USA: Academic Press, an imprint of Elsevier. 549 pp. DOI: https://doi.org/10.1016/B978-0-12-8011850.09983-9.

Ewaze J.O., Moore D. \& Stewart G.R. 1978. Co-ordinate regulation of enzymes involved in ornithine metabolism and its relation to sporophore morphogenesis in Coprinus cinereus. Journal of General Microbiology. 107: 343-357. DOI: https://doi.org/10.1099/00221287-107-2-343.

Etxebeste O., Otamendi A., Garzia A., Espeso E.A. \& Cortese M.S. 2019. Rewiring of transcriptional networks as a major event leading to the diversity of asexual multicellularity in fungi. Critical Reviews in Microbiology. 45: 548-563. DOI: https://doi.org/10.1080/1040841X.2019.1630359.

Fayod V. 1889. Prodrome d'une histoire naturelle des Agaricinés. Annales des Sciences Naturelles, Botanique. Série 7-9: 179-411. Published A. Asher.

Gao W., Qu J., Zhang J., Sonnenberg A., Chen Q., Zhang Y. \& Huang C. 2018. A genetic linkage map of Pleurotus tuoliensis integrated with physical mapping of the de novo sequenced genome and the mating type loci. BMC Genomics. 19(1): article number 18. DOI: https://doi.org/10.1186/s12864-0174421-z.

Goh Y.K., Marzuki N.F., Lim C.K., Goh Y.K. \& Goh K.J. 2016. Cytotoxicity and acute oral toxicity of ascomycetous mycoparasitic Scytalidium parasiticum. Transactions on Science and Technology. 3: 483-488. URL: https://www.transectscience.org/pdfs/vol3/no3/3 3 483-488.html.

Grützmann K., Szafranski K., Pohl M., Voigt K., Petzold A. \& Schuster S. 2014. Fungal alternative splicing is associated with multicellular complexity and virulence: a genome-wide multi-species study. DNA Research. 21: 27-39. DOI: https://doi.org/10.1093/dnares/dst038.

Halbwachs H., Simmel J. \& Bässler C. 2016. Tales and mysteries of fungal fruiting: how morphological and physiological traits affect a pileate lifestyle. Fungal Biology Reviews. 30: 36-61. DOI: https://doi.org/10.1016/i.fbr.2016.04.002.

Hammad F., Watling R. \& Moore D. 1993a. Cell population dynamics in Coprinus cinereus: narrow and inflated hyphae in the basidiome stipe. Mycological Research. 97: 275-282. DOI: https://doi.org/10.1016/S0953-7562(09)81120-9.

Hammad F., Ji J., Watling R. \& Moore D. 1993b. Cell population dynamics in Coprinus cinereus: coordination of cell inflation throughout the maturing fruit body. Mycological Research. 97: 269-274. DOI: https://doi.org/10.1016/S0953-7562(09)81119-2.

Hammond J.B.W. \& Nichols R. 1976. Carbohydrate metabolism in Agaricus bisporus (Lange) Sing.: Changes in soluble carbohydrates during growth of mycelium and sporophore. Journal of General Microbiology. 93: 309-320. DOI: https://doi.org/10.1099/00221287-93-2-309. 
Hapuarachchi K.K., Elkhateeb W.A., Karunarathna S.C., Cheng C.R., Bandara A.R., Kakumyan P., Hyde K.D., Daba G.M. \& Wen T C. 2018. Current status of global Ganoderma cultivation, products, industry and market. Mycosphere. 9(5): 1025-1052. DOI: https://doi.org/10.5943/mycosphere/9/5/6.

Hapuarachchi K.K., Karunarathna S.C., McKenzie E.H.C., Wu X.L., Kakumyan P., Hyde K.D. \& Wen T.C. 2019. High phenotypic plasticity of Ganoderma sinense (Ganodermataceae, Polyporales) in China. Asian Journal of Mycology. 2: 1-47. DOI: https://doi.org/10.5943/ajom/2/1/1.

Harper J.L., Rosen B.R. \& White J. 1986. The Growth and Form of Modular Organisms. London: The Royal Society. 250 pp. ISBN-10: 0521350743, ISBN-13: 978-0521350747.

Hayes W.A., Randle P.E. \& Last F.T. 1969. The nature of the microbial stimulus affecting sporophore formation in Agaricus bisporus (Lange) Sing. Annals of Applied Biology. 64: 177-187. DOI: https://doi.org/10.1111/j.1744-7348.1969.tb02867.x.

He B.-L., You L.-R., Ye Z.-W., Guo L.-Q., Lin J.-F., Wei T. \& Zheng Q.-W. 2018. Construction of novel cold-tolerant strains of Volvariella volvacea through protoplast fusion between Volvariella volvacea and Pleurotus eryngii. Scientia Horticulturae. 230: 161-168. DOI: https://doi.org/10.1016/i.scienta.2017.12.003.

He M.-Q., Zhao R.-L., Hyde K.D., Begerow D., Kemler M. and 65 others. 2019. Notes, outline and divergence times of Basidiomycota. Fungal Diversity. 99: 105-367. DOI: https://doi.org/10.1007/s13225-019-00435-4.

Hibbett D.S., Stajich J.E. \& Spatafora J.W. 2017. Toward genome-enabled mycology. Mycologia. 105: 1339-1349. DOI: https://doi.org/10.3852/13-196.

Horner J. \& Moore D. 1987. Cystidial morphogenetic field in the hymenium of Coprinus cinereus. Transactions of the British Mycological Society. 88: 479-488. DOI: https://doi.org/10.1016/S00071536(87)80031-1.

Hou L., Li Y., Chen M. \& Li Z. 2017. Improved fruiting of the straw mushroom (Volvariella volvacea) on cotton waste supplemented with sodium acetate. Applied Microbiology and Biotechnology. 101(23-24): 8533-8541. DOI: https://doi.org/10.1007/s00253-017-8476-1.

Iten W. 1970. Zur funktion hydrolytischer enzyme bei der autolysate von Coprinus. Berichte Schweizerische Botanische Gesellschaft. 79: 175-198.

Iten W. \& Matile P. 1970. Role of chitinase and other lysosomal enzymes of Coprinus lagopus in the autolysis of fruiting bodies. Journal of General Microbiology. 61: 301-309. DOI: https://doi.org/10.1099/00221287-61-3-301.

lyer L.M., Zhang D., de Souza R.F., Pukkila P.J., Rao A. \& Aravind L. 2014. Lineage-specific expansions of TET/JBP genes and a new class of DNA transposons shape fungal genomic and epigenetic landscapes. Proceedings of the National Academy of Sciences of the United States of America. 111: 1676-1683. DOI: https://doi.org/10.1073/pnas.1321818111.

Junior Letti L.A., Destéfanis Vítola F.M., Vinícius de Melo Pereira G., Karp S.G., Pedroni Medeiros A.B. et al. 2018. Solid-state fermentation for the production of mushrooms. In: Current Developments in Biotechnology and Bioengineering: Current Advances in Solid-State Fermentation, (eds A. Pandey, C. Larroche \& C.R. Soccol). Chapter 14, pp. 285-318. Amsterdam: Elsevier. ISBN 9780444639905. DOI: https://doi.org/10.1016/B978-0-444-63990-5.00014-1.

Kang L., Zhou Ji., Wang R., Zhang X., Liu C., Liu Z. \& Yuan S. 2019a. Glucanase-induced stipe wall extension shows distinct differences from chitinase-induced stipe wall extension of Coprinopsis cinerea. Applied and Environmental Microbiology. 85: article number e01345-19. DOI: https://doi.org/10.1128/AEM.01345-19. 
Kang L., Zhu Y., Bai Y. \& Yuan S. 2019b. Characteristics, transcriptional patterns and possible physiological significance of glycoside hydrolase family 16 members in Coprinopsis cinerea. FEMS Microbiology Letters. 366: article number fnz083. DOI: https://doi.org/10.1093/femsle/fnz083.

Kemp R.F.O. 1977. Oidial homing and the taxonomy and speciation of basidiomycetes with special reference to the genus Coprinus. In: The Species Concept in Hymenomycetes (ed. H. Clemençon), pp. 259-273. Vaduz: J. Cramer. ISBN-10: 3768211738, ISBN-13: 978-3768211734.

Kerrigan R.W., Challen M.P. \& Burton K.S. 2013. Agaricus bisporus genome sequence: a commentary. Fungal Genetics and Biology. 55: 2-5. DOI: https://doi.org/10.1016/i.fglb.2013.03.002.

Krizsán K., Almási É., Merényi Z., Sahu N., Virágh M. and 19 others. 2019. Transcriptomic atlas of mushroom development reveals conserved genes behind complex multicellularity in fungi. Proceedings of the National Academy of Sciences of the United States of America. 116: 7409-7418. DOI: https://doi.org/10.1073/pnas.1817822116.

Kües U., Khonsuntia W. \& Subba S. 2018. Complex fungi. Fungal Biology Reviews. 32: 205-218. DOI: https://doi.org/10.1016/i.fbr.2018.08.001.

Kües U. \& Navarro-González M. 2015. How do Agaricomycetes shape their fruiting bodies? 1. Morphological aspects of development. Fungal Biology Reviews. 29: 63-97. DOI: https://doi.org/10.1016/i.fbr.2015.05.001.

Lam K.-L., Si K., Wu X., Tang S., Sun X., Kwan H-S. \& Cheung P. C-K. 2018. The diploid genome of the only sclerotia-forming wild-type species in the genus Pleurotus - Pleurotus tuber-regium - provides insights into the mechanism of its biomass conversion from lignocellulose substrates. Journal of Biotechnology. 283: 22-27. DOI: https://doi.org/10.1016/j.jbiotec.2018.07.009.

Lau A. Y-T., Cheng X., Cheng C.K., Nong W., Cheung M.K., Chan R.H.-F., Hui J.H.L. \& Kwan H.S. 2018. Discovery of microRNA-like RNAs during early fruiting body development in the model mushroom Coprinopsis cinerea. PLoS ONE. 13: article e0198234. DOI: https://doi.org/10.1371/journal.pone.0198234.

Leptin M. 2005. Gastrulation movements: the logic and the nuts and bolts. Developmental Cell. 8: 305320. DOI: https://doi.org/10.1016/j.devcel.2005.02.007.

Lesch B.J. \& Page D.C. 2014. Poised chromatin in the mammalian germ line. Development. 141: 3619-3626. DOI: https://doi.org/10.1242/dev.113027.

Li Y., Cho K.Y., Wu Y.Z. \& Nair N.G. 1992. The effect of lipids and temperature on the physiology and growth of Volvariella volvacea. World Journal of Microbiology \& Biotechnology. 18: 621-626. DOI: https://doi.org/10.1007/BF01238801.

Liseron-Monfils C. \& Ware D. 2015. Revealing gene regulation and associations through biological networks. Current Plant Biology. 3-4: 30-39. DOI: https://doi.org/10.1016/j.cpb.2015.11.001.

Loftus M.G., Moore D. \& Elliott T.J. 1988. DNA polymorphisms in commercial and wild strains of the cultivated mushroom, Agaricus bisporus. Theoretical and Applied Genetics. 76: 712-718. DOI: http://dx.doi.org/10.1007/BF00303517.

Ma Z., Ye C., Deng W., Xu M., Wang Q., Liu G., Wang F., Liu L., Xu Z., Shi G. \& Ding Z. 2018. Reconstruction and analysis of a genome-scale metabolic model of Ganoderma lucidum for improved extracellular polysaccharide production. Frontiers in Microbiology. 9: article number 3076. DOI: http://dx.doi.org/10.3389/fmicb.2018.03076.

Majcherczyk A., Durnte B., Subba S., Zomorrodi M. \& Kües U. 2019. Proteomes in primordia development of Coprinopsis cinerea. Acta Edulis Fungi. 26: 37-50. DOI: https://doi.org/10.16488/j.cnki.1005-9873.2019.03.005. 
Matthews T.R. \& Niederpruem D.J. 1972. Differentiation in Coprinus lagopus. I. Control of fruiting and cytology of initial events. Archiv für Mikrobiologie. 87: 257-268. DOI: https://doi.org/10.1007/BF00424886.

Mau J.L., Chyau C., Li J.Y. \& Tseng Y.H. 1997. Flavor compounds in straw mushroom Volvariella volvacea harvested at different stages of maturity. Journal of Agricultural and Food Chemistry. 45, 4726-4729. DOI: https://doi.org/10.1021/if9703314.

Meinhardt H. 1976. Morphogenesis of lines and nets. Differentiation. 6: 117-123. DOI: https://doi.org/10.1111/i.1432-0436.1976.tb01478.x.

Meinhardt H. 1984. Models of pattern formation and their application to plant development. In: Positional Controls in Plant Development (P. W. Barlow \& D. J. Carr, eds), pp. 1-32. Cambridge, UK: Cambridge University Press. ISBN-10: 052125406X, ISBN-13: 978-0521254069.

Meinhardt H. \& Gierer A. 1974. Applications of a theory of biological pattern formation based on lateral inhibition. Journal of Cell Science. 15: 321-346. URL: http://jcs.biologists.org/content/15/2/321.abstract.

Meyerowitz E.M. 1999. Plants, animals and the logic of development. Trends in Cell Biology. 9: M65M68. DOI: https://doi.org/10.1016/S0962-8924(99)01649-9.

Michaelson J.J., Loguercio S. \& Beyer A. 2009. Detection and interpretation of expression quantitative trait loci (eQTL). Methods. 48: 265-276 (special issue on Global approaches to study gene regulation). DOI: https://doi.org/10.1016/i.ymeth.2009.03.004.

Monro K. \& Poore A.G.B. 2004. Selection in modular organisms: is intraclonal variation in macroalgae evolutionarily important? The American Naturalist. 163: 564-578. DOI: https://doi.org/10.1086/382551.

Montoya S., López D.M. \& Segura B. 2018. Influencia de la luz azul sobre la productividad del cultivo sólido de Ganoderma lucidum. Revista Colombiana de Biotecnología. 20(1): 51-58. DOI: https://doi.org/10.15446/rev.colomb.biote.v20n1.73674.

Moore D. 1995. Tissue formation. In: The Growing Fungus (eds N.A.R. Gow \& G.M. Gadd), pp. 423465. London: Chapman \& Hall. ISBN-10: 0412466007, ISBN-13: 978-0412466007.

Moore D. 1998a. Fungal Morphogenesis. Developmental and Cell Biology Series. Cambridge, UK: Cambridge University Press. DOI: http://doi.org/10.1017/CBO9780511529887.

Moore D. 1998b. Tolerance of imprecision in fungal morphogenesis. In: Proceedings of the Fourth Conference on the Genetics and Cellular Biology of Basidiomycetes, (eds L.J.L.D. Van Griensven \& J. Visser), pp. 13-19. The Mushroom Experimental Station: Horst, The Netherlands. Download full text: https://www.researchgate.net/publication/326406024 Tolerance of imprecision in fungal morphoge nesis.

Moore D. 2013a. Fungal Biology in the Origin and Emergence of Life. Cambridge, UK: Cambridge University Press. 230 pp. ISBN-10: 1107652774, ISBN-13: 978-1107652774.

Moore D. 2013b. Coprinopsis: an autobiography. Publisher: CreateSpace Independent Publishing Platform. 216 pp. ISBN-10: 1482618974; ISBN-13: 9781482618976.

Moore D. \& Chiu S.W. 2001. Fungal products as Food. In: Bio-Exploitation of Filamentous Fungi (eds S.B. Pointing \& K.D. Hyde), 223-251. Hong Kong: Fungal Diversity Press. ISBN: 962-85677-2-1.

Moore D., Elhiti M.M.Y. \& Butler R.D. 1979. Morphogenesis of the carpophore of Coprinus cinereus. New Phytologist. 83: 695-722. DOI: https://doi.org/10.1111/j.1469-8137.1979.tb02301.x.

Moore D. \& Ewaze J.O. 1976. Activities of some enzymes involved in metabolism of carbohydrate during sporophore development in Coprinus cinereus. Journal of General Microbiology. 97: 313-322. DOI: https://doi.org/10.1099/00221287-97-2-313. 
Moore D., Gange A.C., Gange E.G. \& Boddy L. 2008. Fruit bodies: their production and development in relation to environment. In: Ecology of Saprotrophic Basidiomycetes (L. Boddy, J.C. Frankland \& P. van West, eds), pp. 79-103. Amsterdam: Elsevier. ISBN-10: 0123741858, ISBN-13: 9780123741851.

Moore D., Horner J. \& Liu M. 1987a. Co-ordinate control of ammonium-scavenging enzymes in the fruit body cap of Coprinus cinereus avoids inhibition of sporulation by ammonium. FEMS Microbiology Letters. 44: 239-242. DOI: https://doi.org/10.1111/i.1574-6968.1987.tb02275.x.

Moore D. \& Meškauskas A. 2006. A comprehensive comparative analysis of the occurrence of developmental sequences in fungal, plant and animal genomes. Mycological Research. 110: 251-256. DOI: https://doi.org/10.1016/j. mycres.2006.01.003.

Moore D. \& Meškauskas A. 2009. Where are the sequences that control multicellular development in filamentous fungi? In: Current Advances in Molecular Mycology, (eds Y. Gherbawy, R.L. Mach \& M. Rai), pp. 1-37. Nova Science Publishers ISBN 10: 1604569093, ISBN 13: 9781604569094.

Moore D. \& Novak Frazer L. 2002. Essential Fungal Genetics. New York: Springer-Verlag. ISBN-10: 0387953671, ISBN-13: 978-0387953670.

Moore D. \& Novak Frazer L. 2017. Fungiflex: the untold story, 114 pages. Publisher: CreateSpace Independent Publishing Platform. ISBN-10: 1547168560, ISBN-13: 978-1547168569.

Moore D., Robson G.D. \& Trinci A.P.J. 2020. 21st Century Guidebook to Fungi, second edition. Cambridge University Press. London, UK. 600 pp. ISBN: 9781108745680; www.cambridge.org/9781108745680.

Moore D., Walsh C. \& Robson G.D. 2005. A search for developmental gene sequences in the genomes of filamentous fungi. In: Applied Mycology and Biotechnology, vol. 6, Genes, Genomics and Bioinformatics. (D.K. Arora \& R. Berka, eds), pp. 169-188. Amsterdam: Elsevier Science. CLICK HERE to download the full text.

Morin E., Kohler A., Baker A.R., Foulongne-Orio, M., Lombard V. and 38 others. 2012. Genome sequence of the button mushroom Agaricus bisporus reveals mechanisms governing adaptation to a humic-rich ecological niche. Proceedings of the National Academy of Sciences of the United States of America. 109(43): 17501-17506. DOI: https://doi.org/10.1073/pnas.1206847109.

Muraguchi H., Umezawa K., Niikura M., Yoshida M., Kozaki T., and 20 others. 2015. Strand-specific RNA-Seq analyses of fruiting body development in Coprinopsis cinerea. PLOS ONE. 10: article number e0141586. DOI: https://doi.org/10.1371/journal.pone.0141586.

Nagy L.G., Kovács G.M. \& Krizsán K. 2018. Complex multicellularity in fungi: evolutionary convergence, single origin, or both? Biological Reviews. 93: 1778-1794. DOI: https://doi.org/10.1111/brv.12418.

Noble R., Dobrovin-Pennington A., Hobbs P.J. Pederby J. \& Rodger A. 2009. Volatile C8 compounds and pseudomonads influence primordium formation of Agaricus bisporus. Mycologia. 101: 583-591, DOI: https://doi.org/10.3852/07-194.

O’Connor E., McGowan J., McCarthy C.G.P., Amini A., Grogan H. \& Fitzpatrick D.A. 2019. Whole genome sequence of the commercially relevant mushroom strain Agaricus bisporus var. bisporus ARP23. G3: Genes, Genomes, Genetics. 9(10): 3057-3066. DOI: https://doi.org/10.1534/g3.119.400563.

Ohga S., Cho N. S., Li Y. \& Royse D. J. 2004. Utilization of pulsed power to stimulate fructification of edible mushroom. Mushroom Science. 16: 343-352. DOI: http://www.isms.biz/florida/volume-16-part1 -article-44/.

Patyshakuliyeva A., Jurak E., Kohler A., Baker A., Battaglia E., de Bruijn W., Burton K.S., Challen M.P. et al. 2013. Carbohydrate utilization and metabolism is highly differentiated in Agaricus bisporus. BMC Genomics. 14: article 663. DOI: https://doi.org/10.1186/1471-2164-14-663. 
Pelkmans J.F., Lugones L.G. \& Wösten H.A.B. 2016. Fruiting body formation in basidiomycetes. In: The Mycota, Vol. I. Growth, Differentiation and Sexuality (3rd edn), (ed J. Wendland), pp. 387-405. Cham, Switzerland: Springer International Publishing. DOI: https://doi.org/10.1007/978-3-319-25844715.

Plaza D.F., Lin C.-W., van der Velden N.S.J., Aebi M. \& Künzler M. 2014. Comparative transcriptomics of the model mushroom Coprinopsis cinerea reveals tissue-specific armories and a conserved circuitry for sexual development. BMC Genomics. 15: 492. DOI: https://doi.org/10.1186/1471-2164-15-492.

Redhead S.A. 1987. The Xerulaceae (Basidiomycetes), a family with sarcodimitic tissues. Canadian Journal of Botany. 65: 1551-1562. DOI: https://doi.org/10.1139/b87-214.

Reijnders A.F.M. 1963. Les problèmes du développement des carpophores des Agaricales et de quelques groupes voisins. The Hague: $\mathrm{Dr}$ W. Junk. ISBN-10: 9061936284, ISBN-13: 9789061936282.

Reijnders A.F.M. \& Moore D. 1985. Developmental biology of agarics - an overview. In: Developmental Biology of Higher Fungi (eds D. Moore, L.A. Casselton, D.A. Wood \& J.C. Frankland), pp. 581-595. Cambridge, UK: Cambridge University Press. ISBN-10: 0521301610, ISBN-13: 9780521301619.

Riley R., Salamov A. A., Brown D. W., Nagy L. G., Floudas D. et al. (2014). Extensive sampling of basidiomycete genomes demonstrates inadequacy of the white-rot/brown-rot paradigm for wood decay fungi. Proceedings of the National Academy of Sciences the United States of America. 111(27): 9923-9928. DOI: https://doi.org/10.1073/pnas.1400592111.

Rosin I.V. \& Moore D. 1985a. Origin of the hymenophore and establishment of major tissue domains during fruit body development in Coprinus cinereus. Transactions of the British Mycological Society. 84: 609-619. DOI: https://doi.org/10.1016/S0007-1536(85)80115-7.

Rosin I.V. \& Moore D. 1985b. Differentiation of the hymenium in Coprinus cinereus. Transactions of the British Mycological Society. 84: 621-628. DOI: https://doi.org/10.1016/S0007-1536(85)80116-9.

Royse D.J., Jodon M.H., Antonio G.G. \& May B.P. 1987. Confirmation of intraspecific crossing and single and joint segregation of biochemical loci of Volvariella volvacea. Experimental Mycology. 11: 11-18. DOI: https://doi.org/10.1016/0147-5975(87)90031-4.

Sadiq S., Mahmood-ul-Hassan M., Rafiq N. \& Ahad K. 2019. Spent mushroom compost of Pleurotus ostreatus: a tool to treat soil contaminated with endosulfan. Compost Science \& Utilization. 27(4): 193204. DOI: https://doi.org/10.1080/1065657X.2019.1666067.

Sakamoto Y. 2018. Influences of environmental factors on fruiting body induction, development and maturation in mushroom-forming fungi. Fungal Biology Reviews. 32: 236-248. DOI: https://doi.org/10.1016/j.fbr.2018.02.003.

Sakamoto Y., Nakade K., Sato S., Yoshida K., Miyazaki K., Natsume S. \& Konno N. 2017. Lentinula edodes genome survey and postharvest transcriptome analysis. Applied and Environmental Microbiology. 83: e02990-16. DOI: https://doi.org/10.1128/AEM.02990-16.

Sakamoto Y., Sato S., Ito M., Ando Y., Nakahori K. \& Muraguchi H. 2018. Blue light exposure and nutrient conditions influence the expression of genes involved in simultaneous hyphal knot formation in Coprinopsis cinerea. Microbiological Research. 217: 81-90. DOI: https://doi.org/10.1016/i.micres.2018.09.003.

Sánchez C. 2004. Modern aspects of mushrooms culture technology. Applied Microbiology and Biotechnology. 64: 756-762. DOI: https://doi.org/10.1007/s00253-004-1569-7.

Sánchez C. 2010. Cultivation of Pleurotus ostreatus and other edible mushrooms. Applied Microbiology and Biotechnology. 85(5): 1321-1337. DOI: https://doi.org/10.1007/s00253-009-2343-7. 
Sánchez C. 2017a. Reactive oxygen species and antioxidant properties from mushrooms. Synthetic and Systems Biotechnology. 2(1): 13-22. DOI: https://doi.org/10.1016/i.synbio.2016.12.001.

Sánchez C. 2017b. Bioactives from mushroom and their application. In Food Bioactives: Extraction and Biotechnology Applications (M. Puri, ed), Chapter 2, pp. 23-57. Australia: Springer International Publishing AG. ISBN: 9783319516370. DOI https://doi.org/10.1007/978-3-319-51639-4 2.

Sánchez C., Moore D., Robson G.D. \& Trinci A.P.J. 2020. A 21st century miniguide to fungal biotechnology/Una miniguía del siglo XXI para la biotecnología de hongos. Mexican Journal of Biotechnology. 5(1):11-42. DOI: https://doi.org/10.29267/mxjb.2020.5.1.11.

Sánchez C., Téllez Téllez M., Díaz Godínez G. \& Moore D. 2004. Simple staining detects ultrastructural and biochemical differentiation of vegetative hyphae and fruit body initials in colonies of Pleurotus pulmonarius. Letters in Applied Microbiology. 38(6): 483-487. DOI: https://doi.org/10.1111/i.1472-765X.2004.01517.x.

Shefferson R.P., Jones O.R. \& Salguero-Gómez R. (eds) 2017. The Evolution of Senescence in the Tree of Life. Cambridge, UK: Cambridge University Press. 441 pp. ISBN-10: 1107078504, ISBN-13: 978-1107078505.

Singer R. 1961. Mushrooms and Truffles: Botany, Cultivation and Utilization. Leonard Hill (Books) Ltd: London. ISBN: 9783874292580.

Sohretoglu D. \& Huang S. 2018. Ganoderma lucidum polysaccharides as an anti-cancer agent. AntiCancer Agents in Medicinal Chemistry. 18: 667-674. DOI: https://doi.org/10.2174/1871520617666171113121246.

Sonnenberg A.S.M., Baars J.J.P., Gao W. \& Visser R.G.F. 2017. Developments in breeding of Agaricus bisporus var. bisporus: progress made and technical and legal hurdles to take. Applied Microbiology and Biotechnology. 101: 1819-1829. DOI: https://doi.org/10.1007/s00253-017-8102-2.

Stajich J.E. 2017. Fungal genomes and insights into the evolution of the kingdom. In: The Fungal Kingdom, (eds J. Heitman, B. Howlett, P. Crous, E. Stukenbrock, T. James \& N.A.R. Gow), pp. 619633. Washington, DC: ASM Press. DOI: https://doi.org/10.1128/microbiolspec.FUNK-0055-2016.

Stajich J.E., Wilke S.K., Ahrén D., Au C.H., Birren B.W., and 42 others. 2010. Insights into evolution of multicellular fungi from the assembled chromosomes of the mushroom Coprinopsis cinerea (Coprinus cinereus). Proceedings of the National Academy of Sciences of the United States of America. 107: 11889-11894. DOI: https://doi.org/10.1073/pnas.1003391107.

Sudheer S., Alzorqi I., Manickam S. \& Ali A. 2018. Bioactive compounds of the wonder medicinal mushroom 'Ganoderma lucidum'. In Bioactive Molecules in Food, ed. J.M. Mérillon \& K. Ramawat. Cham, Switzerland: Springer International Publishing, pp 1-31. ISBN: 978-3-319-54528-8. DOI: https://doi.org/10.1007/978-3-319-54528-8 45-1.

Sugano S.S., Suzuki H., Shimokita E., Chiba H., Noji S., Osakabe Y. \& Osakabe K. 2017. Genome editing in the mushroom forming basidiomycete Coprinopsis cinerea, optimized by a high-throughput transformation system. Scientific Reports. 7: 1260. DOI: https://doi.org/10.1038/s41598-017-00883-5.

Sun L., Fu Y., Yang Y., Wang X., Cui W., Li D., Yuan X., Zhang Z., Fu Y. \& Li Y. 2019. Genomic analyses reveal evidence of independent evolution, demographic history, and extreme environment adaptation of Tibetan Plateau Agaricus bisporus. Frontiers in Microbiology. 10: article number 1786. DOI: https://doi.org/10.3389/fmicb.2019.01786.

Takaki K., Yoshida K., Saito T., Kusaka T., Yamaguchi R., Takahashi K. \& Sakamoto, Y. 2014. Effect of electrical stimulation on fruit body formation in cultivating mushrooms. Microorganisms. 2(1): 58-72. DOI: https://doi.org/10.3390/microorganisms2010058. 
Takaki K. Kanesawa K., Yamazaki N., Mukaigawa S., Fujiwara T., Takahasi K., Yamasita K. \& Nagane K. 2009. Effect of pulsed high-voltage stimulation on Pholiota nameko mushroom yield. Acta Physica Polonica A. 115: 953-956. DOI: https://doi.org/10.12693/APhysPolA.115.1062.

Takemaru T. \& Kamada T. 1971. Gene control of basidiocarp development in Coprinus macrorhizus. Reports of the Tottori Mycological Institute (Japan). 9: 21-35.

Takemaru T. \& Kamada T. 1972. Basidiocarp development in Coprinus macrorhizus. I. Induction of developmental variations. Botanical Magazine (Tokyo). 85: 51-57. DOI: https://doi.org/10.1007/BF02489200.

Tan Y.H. \& Moore D. 1994. High concentrations of mannitol in the shiitake mushroom Lentinula edodes. Microbios. 79: 31-35. URL: https://www.ncbi.nlm.nih.gov/pubmed/8078418.

Tan Y.H. \& Moore D. 1995. Glucose catabolic pathways in Lentinula edodes determined with radiorespirometry and enzymic analysis. Mycological Research. 99: 859-866. DOI: https://doi.org/10.1016/S0953-7562(09)80742-9.

ten Hove C.A., Lu K.-J. \& Weijers D. 2015. Building a plant: cell fate specification in the early Arabidopsis embryo. Development. 142: 420-430. DOI: https://doi.org/10.1242/dev.111500.

Thorn R. G. \& Barron G.L. 1984. Carnivorous mushrooms. Science. 224(4644): 76-78. DOI: https://doi.org/10.1126/science.224.4644.76.

Thorn R. G., Moncalvo J. M., Reddy C. A. \& Vilgalys R. 2000. Phylogenetic analyses and the distribution of nematophagy support a monophyletic Pleurotaceae within the polyphyletic PleurotoidLentinoid fungi. Mycologia. 92(2): 241-252. DOI: https://doi.org/10.1080/00275514.2000.12061151.

Umar M.H. \& Van Griensven L.J.L.D. 1997a. Morphological studies on the life span, developmental stages, senescence and death of Agaricus bisporus. Mycological Research. 101: 1409-1422. DOI: https://doi.org/10.1017/S0953756297005212.

Umar M.H. \& Van Griensven L.J.L.D. 1997b. Hyphal regeneration and histogenesis in Agaricus bisporus. Mycological Research. 101: 1025-1032. DOI: https://doi.org/10.1017/S0953756297003869.

Umar M.H. \& Van Griensven L.J.L.D. 1998. The role of morphogenetic cell death in the histogenesis of the mycelial cord of Agaricus bisporus and in the development of macrofungi. Mycological Research. 102: 719-735. DOI: https://doi.org/10.1017/S0953756297005893.

Upadhyay R.C. \& Singh M. 2010. Production of edible mushrooms. In: The Mycota, vol 10, Industrial Applications, pp. 79-97. (ed. M. Hofrichter), Berlin, Heidelberg: Springer Nature AG. ISBN: 9783642114571. DOI: https://doi.org/10.1007/978-3-642-11458-8 4.

Utomo C., Tanjung Z.A., Aditama R., Nurani B., Rika F., Madu P., Antonius D., Tryono R. \& Liwang T. 2019. High quality genome sequence reveals the 12 pseudo-chromosomes of Ganoderma boninense. Cold Spring Harbor Laboratory preprint service bioRxiv: article 817510. DOI: http://dx.doi.org/10.1101/817510.

Van der Valk P. \& Marchant R. 1978. Hyphal ultrastructure in fruit body primordia of the basidiomycetes Schizophyllum commune and Coprinus cinereus. Protoplasma. 95: 57-72. DOI: https://doi.org/10.1007/BF01279695.

Varga T., Krizsán K., Földi C., Dima B., Sánchez-García M. and 57 others. 2019. Megaphylogeny resolves global patterns of mushroom evolution. Nature Ecology \& Evolution. 3: 668-678. DOI: https://doi.org/10.1038/s41559-019-0834-1.

Voigt P., Tee W.-W. \& Reinberg D. 2013. A double take on bivalent promoters. Genes \& Development. 27: 1318-1338. DOI: https://doi.org/10.1101/gad.219626.113. 
Vonk P.J. \& Ohm R.A. 2018. The role of homeodomain transcription factors in fungal development. Fungal Biology Reviews. 32: 219-230. DOI: https://doi.org/10.1016/j.fbr.2018.04.002.

Wagemaker M.J.M., Welboren W., van der Drift C., Jetten M.S.M. Van Griensven L.J.L.D. \& Op den Camp H.J.M. 2005. The ornithine cycle enzyme arginase from Agaricus bisporus and its role in urea accumulation in sporophores. Biochimica et Biophysica Acta (BBA) - Gene Structure and Expression. 1681: 107-115. DOI: https://doi.org/10.1016/i.bbaexp.2004.10.007.

Wang Q., Wang F., Xu Z.H. \& Ding Z.Y. 2017. Bioactive mushroom polysaccharides a review on monosaccharide composition, biosynthesis and regulation. Molecules. 22: E955. DOI: https://doi.org/10.3390/molecules22060955.

Wang S., Meyer E., McKay J.K. \& Matz M.V. 2012. 2b-RAD: a simple and flexible method for genomewide genotyping. Nature Methods. 9(8): 808-810. DOI: https://doi.org/10.1038/nmeth.2023.

Wang Y., Liu J., Huang B., Xu Y.-M., Li J. and six others. 2015. Mechanism of alternative splicing and its regulation. Biomedical Reports. 3: 152-158. DOI: https://doi.org/10.3892/br.2014.407.

Waters H., Moore D. \& Butler R.D. 1975. Morphogenesis of aerial sclerotia of Coprinus lagopus. New Phytologist. 74: 207-213. DOI: https://doi.org/10.1111/j.1469-8137.1975.tb02607.x.

Watling R. \& Moore D. 1994. Moulding moulds into mushrooms: shape and form in the higher fungi. In: Shape and Form in Plants and Fungi, (eds D. S. Ingram \& A. Hudson), pp. 270-290. London: Academic Press. ISBN: 978-0123710352.

Wiemer M., Grimm C. \& Osiewacz H.D. 2016. Molecular control of fungal senescence and longevity. In: The Mycota, Vol. I. Growth, Differentiation and Sexuality (3rd edn), (ed J. Wendland), pp. 155-181. Cham, Switzerland: Springer International Publishing. DOI: https://doi.org/10.1007/978-3-319-2584478.

Wight M. \& Werner A. 2013. The functions of natural antisense transcripts. Essays in Biochemistry. 54: 91-101. DOI: https://doi.org/10.1042/bse0540091.

Williams M.A.J., Beckett A. \& Read N.D. 1985. Ultrastructural aspects of fruit body differentiation in Flammulina velutipes. In: Developmental Biology of Higher Fungi, British Mycological Society Symposium vol. 10, (eds D. Moore, L.A. Casselton, D.A. Wood \& J.C. Frankland), pp. 429-450. Cambridge, UK: Cambridge University Press. ISBN-10: 0521301610, ISBN-13: 978-0521301619.

Williams M.L.K. \& Solnica-Krezel L. 2017. Regulation of gastrulation movements by emergent cell and tissue interactions. Current Opinion in Cell Biology. 48: 33-39. DOI: https://doi.org/10.1016/i.ceb.2017.04.006.

Wood D.A. 1980a. Inactivation of extracellular laccase of Agaricus bisporus. Journal of General Microbiology. 117: 339-345. DOI: https://doi.org/10.1099/00221287-117-2-339.

Wu J., Gao B. \& Zhu S. 2014. The fungal defensin family enlarged. Pharmaceuticals. 7: 866-880. DOI: https://doi.org/10.3390/ph7080866.

Yan Y.-M., Wang X.-L., Luo Q. Jiang L.-P., Yang C.-P., Hou B., Zuo Z.-L., Chen Y.-B. \& Cheng Y.-X. 2015. Metabolites from the mushroom Ganoderma lingzhi as stimulators of neural stem cell proliferation. Phytochemistry. 114: 155-162. DOI: https://doi.org/10.1016/j.phytochem.2015.03.013.

Yoo S., Lee H., Markkandan K., Moon S., Ahn Y.J. et al. 2019. Comparative transcriptome analysis identified candidate genes involved in mycelium browning in Lentinula edodes. BMC Genomics. 20: 121. DOI: https://doi.org/10.1186/s12864-019-5509-4.

Zhang Z., Wen J., Li J., Ma X., Yu Y., Tan X., Liu B., Li X. \& Gong L. 2018. The evolution of genomic and epigenomic features in two Pleurotus fungi. Scientific Reports. 8(1). 8313. DOI: https://doi.org/10.1038/s41598-018-26619-7. 
Zhou J., Kang L., Liu C., Niu X., Wang X., Liu H., Zhang W., Liu Z., Latgé J.-P. \& Yuan, S. 2019. Chitinases play a key role in stipe cell wall extension in the mushroom Coprinopsis cinerea. Applied and Environmental Microbiology. 85: article number e00532-19. DOI: https://doi.org/10.1128/AEM.00532-19.

Zhou L.W., Cao Y., Wu S.H., Vlasák J., Li D.W., Li M.J. \& Dai Y.C. 2015. Global diversity of the Ganoderma lucidum complex (Ganodermataceae, Polyporales) inferred from morphology and $\begin{array}{lllll}\text { multilocus } & \text { phylogeny. } & \text { Phytochemistry. } & \text { 114: } & \text { 7-15. }\end{array}$ https://doi.org/10.1016/i. phytochem.2014.09.023.

Zhou S., Tang Q., Tang C., Liu Y., Ma F., Zhang X. \& Zhang J. 2018. Triterpenes and soluble polysaccharide changes in Lingzhi or Reishi medicinal mushroom, Ganoderma lucidum (Agaricomycetes), during fruiting growth. International Journal of Medicinal Mushrooms. 20: 859-871. DOI: https://doi.org/10.1615/IntJMedMushrooms.v20.i9.

Zhou X.W. 2017. Cultivation of Ganoderma lucidum. In: Edible and Medicinal Mushrooms: Technology and Applications, (eds C.Z. Diego \& A. Pardo-Giménez), pp. 385-413. Chichester, UK: John Wiley \& Sons (Wiley-Blackwell). DOI: https://doi.org/10.1002/9781119149446.ch18.

Zhou X.W., Su K.Q. \& Zhang Y.M. 2012. Applied modern biotechnology for cultivation of Ganoderma and development of their products. Applied Microbiology and Biotechnology. 93(3): 941-963. DOI: https://doi.org/10.1007/s00253-011-3780-7. 